\title{
Immunotherapy of Multiple Myeloma: Promise and Challenges
}

\section{Hanley N Abramson}

Wayne State University, Department of Pharmaceutical Sciences, Detroit, MI, 4820I, USA
Correspondence: Hanley N Abramson Wayne State University, Department of Pharmaceutical Sciences, 259 Mack Ave, Detroit, Mi, 4820I, USA

Tel + I 2484205335

Email ac253I@wayne.edu
Abstract: Whereas the treatment of MM was dependent solely on alkylating agents and corticosteroids during the prior three decades, the landscape of therapeutic measures to treat the disease began to expand enormously early in the current century. The introduction of new classes of small-molecule drugs, such as proteasome blockers (bortezomib and carfilzomib), immunomodulators (lenalidomide and pomalidomide), nuclear export inhibitors (selinexor), and histone deacetylase blockers (panobinostat), as well as the application of autologous stem cell transplantation (ASCT), resulted in a seismic shift in how the disease is treated. The picture changed dramatically once again starting with the 2015 FDA approval of two monoclonal antibodies (mAbs) - the anti-CD38 daratumumab and the anti-SLAMF7 elotuzumab. Daratumumab, in particular, has had a great impact on MM therapy and today is often included in various regimens to treat the disease, both in newly diagnosed cases and in the relapse/refractory setting. Recently, other immunotherapies have been added to the arsenal of drugs available to fight this malignancy. These include isatuximab (also antiCD38) and, in the past year, the antibody-drug conjugate (ADC) belantamab mafodotin and the chimeric antigen receptor (CAR) T-cell product idecabtagene vicleucel (ide-cel). While the accumulated benefits of these newer agents have resulted in a doubling of the disease's five-year survival rate to more than 5 years and improved quality of life, the disease remains incurable. Almost without exception patients experience relapse and/or become refractory to the drugs used, making the search for innovative therapies all the more essential. This review covers the current scope of anti-myeloma immunotherapeutic agents, both those in clinical use and on the horizon, including naked mAbs, ADCs, bi- and multi-targeted mAbs, and CAR T-cells. Emphasis is placed on the benefits of each along with the challenges that need to be overcome if MM is to be considered curable in the future.

Keywords: multiple myeloma, monoclonal antibodies, antibody-drug conjugates, bi-specific antibodies, chimeric antigen receptor T-cells, cytokine release syndrome

\section{Introduction}

Multiple myeloma (MM) is characterized by clonal proliferation of plasma cells in the bone marrow accompanied by high levels of monoclonal immunoglobulins in the urine and/or blood. In the United States, the disease ranks second behind nonHodgkin's lymphoma (NHL) as a hematological cancer and 14th among all cancers in terms of incidence. According to current estimates, in $2021 \mathrm{MM}$ will be diagnosed in a total of 34,920 individuals (55.3\% male) and will be responsible for 12,410 deaths in the U.S. ${ }^{1}$ The median age at diagnosis is 69 years, which has been trending lower in recent years. Significant racial disparities have been noted for all stages of MM with the prevalence of the disease in the US being 
substantially greater among African Americans than among Caucasians. ${ }^{2}$ For example, in one analysis of the SEER (Surveillance, Epidemiology, and End Results) data base, maintained by the National Cancer Institute (NCI), it was found that the annual incidence of the disease per 100,000 population among Caucasians is 6.1 for men and 4.0 for women compared to 13.2 and 9.6, respectively, for African Americans. ${ }^{3}$

The tetrad of symptoms that typically accompanies an active case of MM is known by the acronym CRAB: hypercalcemia, renal insufficiency, anemia, and bone lesions. An active case often is preceded by an asymptomatic state, monoclonal gammopathy of undetermined significance (MGUS), with a risk of progression from MGUS to MM of about $1 \%$ per year. ${ }^{4} \mathrm{~A}$ second asymptomatic phase, smoldering multiple myeloma (SMM), intermediate between MGUS and MM, also has been described. ${ }^{5,6}$ Current guidelines for the diagnosis and treatment of MM have been issued by the National Comprehensive Cancer Network (NCCN). ${ }^{7}$ While the cause of MM remains unknown, cytogenetic anomalies are known to play a role in some MM patients classified as "high risk". The most frequently encountered of these variances are the chromosomal deletion $\operatorname{del}(17 \mathrm{p})$ and the transversions $\mathrm{t}(14 ; 16)$ and $\mathrm{t}(4 ; 14){ }^{8}$

Remarkable progress has attended the treatment of MM over the past half century. Starting in the mid-1960's and continuing for nearly three decades, two alkylating agents, melphalan $\left(\text { Alkeran }^{\circledR}\right)^{9}$ and cyclophosphamide $\left(\right.$ Cytoxan $\left.^{\circledR}\right)$, often in regimens that included corticosteroids, were the mainstays of MM therapy. The addition of autologous stem cell transplantation (ASCT) to the MM treatment landscape in the 1990s further improved therapeutic outcomes. However, the picture began to change dramatically by the end of the decade with the discovery of thalidomide's remarkable immunomodulatory effects that conferred antimyeloma activity on this once ignominiously regarded drug. Two close chemical derivatives of thalidomide, lenalidomide $\left(\right.$ Revlimid $\left.^{\circledR}\right)$ (2005) and pomalidomide (Pomalyst ${ }^{\circledR}$ ) (2013), soon supplanted thalidomide for MM. Meanwhile, the discovery of the potent anti-myeloma actions of proteasome inhibitors led to the introduction of bortezomib (Velcade ${ }^{\circledR}$ ) (2003), later followed by the mechanistically similar carfilzomib (Kyprolis ${ }^{\circledR}$ ) and ixazomib (Ninlaro ${ }^{\circledR}$ ), as important additions to the anti-myeloma arsenal. The list of US Food and Drug Administration (FDA)-approved small molecules that work by additional mechanisms to treat MM has recently expanded to include the pan-histone deacetylase inhibitor panobinostat $\left(\right.$ Farydak $\left.^{\circledR}\right)$ (2015) and the nuclear export blocker selinexor $\left(\right.$ Xpovio $\left.^{\circledR}\right)$ (2019). The cumulative benefits of these therapeutic advances can be seen in the 2.26-fold increase of the MM five-year survival rate over the period from $1975-77(24.6 \%)$ to $2011-17(55.6 \%),{ }^{10}$ as well as in the median survival, which has increased from 2.5 years in the mid-1990s to 5.7 years today. ${ }^{11}$

Treatment options for MM underwent a paradigm shift beginning with the 2015 approval by the FDA of two monoclonal antibodies (mAbs), daratumumab $\left(\right.$ Darzalex $^{\circledR}$ ) and elotuzumab (Empliciti ${ }^{\circledR}$ ), followed by additional immunotherapies, including a third $\mathrm{mAb}$, isatuximab (Sarclisa ${ }^{\circledR}$ ), an antibody-drug conjugate (belantamab mafodotin; Blenrep ${ }^{\circledR}$ ), and idecabtagene vicleucel $\left(\right.$ Abecma ${ }^{\circledR}$ ), the first chimeric antigen receptor (CAR) T-cell product for the disease. This review is intended to cover the fundamental aspects of these newer agents and the prospects for additional immunotherapeutic agents that now occupy the anti-myeloma pipeline. ${ }^{12}$ For recent reviews of the background, history, and current status of the applications of immunotherapy to cancer treatment, the reader is directed to the recent publications of Esfahani, ${ }^{13}$ Waldman, ${ }^{14}$ and Tan. ${ }^{15}$

\section{CD38 as a Monoclonal Antibody Target}

CD38, which has elicited much interest as a target in MM, is a $45 \mathrm{kDa}$ transmembrane glycoprotein, expressed at high levels in both normal and neoplastic plasma cells, as well as at lower levels by a number of other blood cells. ${ }^{16}$ This important surface biomarker is known to perform several roles in cells. These functions include, among others, acting as a receptor for CD31 (platelet endothelial cell adhesion molecule; PECAM-1) and as an ectoenzyme with cyclic ADP ribose hydrolase activity, the products of which are important regulators of intracellular calcium levels. ${ }^{17,18}$

The principal mechanisms by which anti-CD38 antibodies are lethal to myeloma cells are three-fold: antibody-dependent cellular cytotoxicity (ADCC), antibody-dependent cellular phagocytosis (ADCP), and complement-dependent cytotoxicity (CDC). In addition, crosslinks between CD38 on myeloma cells and effector cell $\mathrm{Fc} \gamma$ receptors may be responsible for initiation of apoptosis of myeloma cells. ${ }^{19}$ Moreover, antiCD38 antibodies have demonstrated immunomodulatory actions by blocking myeloid-derived suppressor cells and regulatory T- and B-cells. ${ }^{20}$ 
In 2015, daratumumab, a fully human IgG1k mAb directed against $\mathrm{CD} 38$, became the first immunotherapeutic agent approved for treatment of MM. Approval was granted based on supporting data from two Phase III trials - CASTOR (NCT02136134) and POLLUX (NCT02076009) - wherein the mAb and dexamethasone were combined with either a proteasome inhibitor (bortezomib) ${ }^{21}$ or an immunomodulator (lenalidomide). ${ }^{22}$ Initial approval limited daratumumab-dexamethasone use to monotherapy in patients who had relapsed following a minimum of three prior therapies that included either a proteasome inhibitor or an immunomodulator. However, daratumumab-dexamethasone in combination with proteasome inhibitors and/or immunomodulators has since assumed a key role in even earlier courses of antimyeloma therapy as data from additional phase III trials demonstrated more sustained responses and good tolerability from such combinations, including use in newly diagnosed patients whether ASCT-eligible ${ }^{23}$ or -ineligible. ${ }^{24}$

Current NCCN treatment guidelines for MM, based on most favorable response and safety data, include one triplet protocol (daratumumab- lenalidomidedexamethasone); and a number of quartet regimens which include, in addition to daratumumab-bortezomibcorticosteroid (dexamethasone or prednisone), either an alkylating agent (cyclophosphamide or melphalan) or an immunomodulator (lenalidomide or thalidomide). ${ }^{7}$ Moreover, combinations with pomalidomide ${ }^{25}$ and more recently carfilzomib ${ }^{26,27}$ also have received FDA approval for use in relapsed and/or refractory MM (RRMM). Several network meta-analytic studies of random controlled trials provide further evidence of daratumumab's benefits in various myeloma-based settings. ${ }^{28}$ In addition, recent FDA approval of a subcutaneous (sc) formulation of daratumumab combined with hyaluronidase provides the substantial benefit of enabling markedly shorter administration times $-3-5$ minutes vs several hours of intravenous (iv) infusion of the $\mathrm{mAb}$ without compromising efficacy or patient safety. ${ }^{29-31}$

Infusion reactions, which include dyspnea, rash, headache, cough, nausea, vomiting, and nasal congestion represent an adverse, although generally low grade, effect of daratumumab, being noted in up to $50 \%$ of patients receiving the drug, especially during the first two infusions. Pre-medication with a glucocorticoid and/or a leukotriene blocker (montelukast) may help mitigate this effect and may be particularly useful in patients with underlying respiratory disease. ${ }^{32}$ Also, the drug can interfere with blood typing due to its capacity for binding to $\mathrm{CD} 38$ on reagent blood cells, resulting in a positive indirect Coombs test. This can be circumvented by conducting patient blood-typing procedures prior to using daratumumab. ${ }^{33}$ The risk of infection, primarily due to the bone marrow suppression, also has been shown to accompany use of the agent and necessitates use of prophylactic antimicrobials, such as cotrimoxazole to prevent Pneumocystis carinii pneumonia and antivirals. Table 1 contains a partial list of current clinical trials that include daratumumab.

Isatuximab, a more recent addition to the anti-CD38 $\mathrm{mAb}$ arsenal, differs from daratumumab in that it represents a chimeric mouse-human IgG1k construct. Its mechanism of action is similar to that of daratumumab although cross-linking apparently is not a prerequisite for apoptosis induction. ${ }^{49}$ Initial FDA approval of isatuximab (March 2020) specified its use for the treatment of RRMM in combination with pomalidomide and dexamethasone in patients who have failed at least two prior therapies, including lenalidomide and a proteasome inhibitor. ${ }^{50}$ This was based on the results of the phase III ICARIA trial in which addition of isatuximab to RRMM patients receiving pomalidomide-dexamethasone exhibited significantly longer PFS (11.5 months vs 6.5 months). ${ }^{51,52}$ Subsequently (March 2021), the combination of isatuximab-dexamethasone with carfilzomib was approved for treatment of RRMM patients who had received one to three prior therapies. Approval in this case was predicated on efficacy and safety data from the phase III IKEMA study (NCT03275285) in which the cohort receiving the isatuximab-based regimen exhibited a $45 \%$ reduction in the risk of disease progression or death compared to that given carfilzomib-dexamethasone alone. ${ }^{53-55}$ Infusion reactions and upper respiratory infections are the most common adverse reactions noted for isatuximab. An isatuximab formulation intended for subcutaneous use is currently the subject of an ongoing clinical trial (NCT04045795). Several of the current isatuximabcontaining clinical trials are shown in Table 2.

Other anti-CD38 mAbs that have been investigated for MM include felzartamab (MOR202), TAK-573, and mezagitamab (TAK-079). The first of these has been dropped by its sponsor from further consideration in MM while the other two, developed by Takeda, remain in early phase clinical trials - NCT03215030 (iv) and NCT03984097 (sc), respectively. 
Table I Selected Clinical Trials of Daratumumab in Multiple Myeloma (MM)

\begin{tabular}{|c|c|c|c|c|}
\hline $\begin{array}{l}\text { Trial ID } \\
\text { (References) }\end{array}$ & Treatment & Phase & $\begin{array}{l}\text { Enrollment } \\
(\mathbf{N})\end{array}$ & Trial Title \\
\hline NCT0465695I & Dara & II & 160 & $\begin{array}{l}\text { Daratumumab for first Line treatment of transplant-ineligible myeloma } \\
\text { patients followed by daratumumab re-treatment at first relapse } \\
\text { (GMMG-DADA) }\end{array}$ \\
\hline NCT0262648I ${ }^{34}$ & Dara + Dex & ॥ & 64 & $\begin{array}{l}\text { A multicenter open label Phase II study of daratumumab in combination } \\
\text { with dexamethasone in MM resistant or refractory to bortezomib and } \\
\text { lenalidomide and pomalidomide }\end{array}$ \\
\hline NCT0254I383 23,35 & $\begin{array}{l}\text { Dara alone vs (Bort } \\
+ \text { Thal }+ \text { Dex } \pm \\
\text { Dara) }\end{array}$ & III & 1085 & $\begin{array}{l}\text { Study of daratumumab in combination with bortezomib, thalidomide, } \\
\text { and dexamethasone (VTd) in the first line treatment of transplant } \\
\text { eligible subjects with newly diagnosed MM (Cassiopeia) }\end{array}$ \\
\hline NCT03993912 & $\begin{array}{l}(\text { Len + Dex) vs (Len } \\
+ \text { Dex + Dara sc) }\end{array}$ & III & 294 & $\begin{array}{l}\text { A phase III study comparing lenalidomide and subcutaneous } \\
\text { daratumumab (R-dara sc) vs lenalidomide and dexamethasone (Rd) in } \\
\text { frail subjects with previously untreated MM who are ineligible for high } \\
\text { dose therapy }\end{array}$ \\
\hline NCT02316106 36 & Dara & ॥ & 123 & $\begin{array}{l}\text { A randomized phase II trial to evaluate three daratumumab dose } \\
\text { schedules in smoldering MM }\end{array}$ \\
\hline NCT03। $58688^{26,37,38}$ & $\begin{array}{l}(\text { Carf }+ \text { Dex }) \pm \\
\text { Dara }\end{array}$ & III & 466 & $\begin{array}{l}\text { A randomized, open-label, phase III study comparing carfilzomib, } \\
\text { dexamethasone, and daratumumab to carfilzomib and dexamethasone } \\
\text { for the treatment of patients with RRMM (CANDOR) }\end{array}$ \\
\hline NCT02। $36134^{21,39}$ & $\begin{array}{l}(\text { Bort }+ \text { Dex }) \pm \\
\text { Dara }\end{array}$ & III & 499 & $\begin{array}{l}\text { Phase III study comparing daratumumab, bortezomib and } \\
\text { dexamethasone (DVd) vs bortezomib and dexamethasone (Vd) in } \\
\text { subjects with RRMM (CASTOR) }\end{array}$ \\
\hline NСT0330I220 40 & Dara sc + Hyal & III & 390 & $\begin{array}{l}\text { A phase III randomized, multicenter study of subcutaneous } \\
\text { daratumumab versus active monitoring in subjects with high-risk } \\
\text { smoldering MM (AQUILA) }\end{array}$ \\
\hline NCT0390I963 & Len \pm Dara & III & 214 & $\begin{array}{l}\text { A randomized study of daratumumab plus lenalidomide versus } \\
\text { lenalidomide alone as maintenance treatment in patients with newly } \\
\text { diagnosed MM who are minimal residual disease positive after frontline } \\
\text { ASCT }\end{array}$ \\
\hline NCT02076009 $22,41,42$ & $($ Len + Dex $) \pm$ Dara & III & 569 & $\begin{array}{l}\text { Phase III study comparing daratumumab, lenalidomide, and } \\
\text { dexamethasone (DRd) vs lenalidomide and dexamethasone (Rd) in } \\
\text { subjects with RRMM (POLLUX) }\end{array}$ \\
\hline NCT03 $180736^{43}$ & $\begin{array}{c}(\text { Pom }+ \text { Dex }) \pm \\
\text { Dara }\end{array}$ & III & 304 & $\begin{array}{l}\text { A phase III study comparing pomalidomide and dexamethasone with or } \\
\text { without daratumumab in subjects with RRMM who have received at } \\
\text { least one prior line of therapy with both lenalidomide and a proteasome } \\
\text { inhibitor (Apollo) }\end{array}$ \\
\hline NCT04649060 & Dara \pm Melf & III & 240 & $\begin{array}{l}\text { A randomized, controlled, open-label phase III study of melflufen in } \\
\text { combination with daratumumab compared with daratumumab in } \\
\text { patients with RRMM (LIGHTHOUSE) }\end{array}$ \\
\hline NCT022521 $72^{44,45}$ & $($ Len + Dex $) \pm$ Dara & III & 737 & $\begin{array}{l}\text { A phase III study comparing daratumumab, lenalidomide, and } \\
\text { dexamethasone (DRd) vs lenalidomide and dexamethasone (Rd) in } \\
\text { subjects with previously untreated MM who are ineligible for high dose } \\
\text { therapy (MAIA) }\end{array}$ \\
\hline
\end{tabular}

(Continued) 
Table I (Continued).

\begin{tabular}{|l|c|c|c|l|}
\hline $\begin{array}{l}\text { Trial ID } \\
\text { (References) }\end{array}$ & Treatment & Phase & $\begin{array}{c}\text { Enrollment } \\
\text { (N) }\end{array}$ & Trial Title \\
\hline $\begin{array}{l}\text { NCT03652064 } \\
\text { (Bort + Len + Dex) } \\
\pm \text { Dara }\end{array}$ & III & 395 & $\begin{array}{l}\text { A phase III study comparing daratumumab, bortezomib, lenalidomide, } \\
\text { and dexamethasone (D-VRd) with bortezomib, lenalidomide, and } \\
\text { dexamethasone (VRd) in subjects with untreated MM and for whom } \\
\text { ASCT is not planned as initial therapy }\end{array}$ \\
\hline NCT032771054-48 & Dara (sc vs iv) & III & 522 & $\begin{array}{l}\text { A phase III randomized, multicenter study of subcutaneous vs } \\
\text { intravenous administration of daratumumab in subjects with RRMM } \\
\text { (COLUMBA) }\end{array}$ \\
\hline
\end{tabular}

Abbreviations: Bort, bortezomib; Carf, carfilzomib; Dara, daratumumab; Dex, dexamethasone; Hyal, hyaluronidase; iv, intravenous; Len, lenalidomide; Melf, melflufen; Pom, pomalidomide; sc, subcutaneous; Thal, thalidomide.

Table 2 Selected Clinical Trials of Isatuximab in Multiple Myeloma (MM)

\begin{tabular}{|c|c|c|c|c|}
\hline $\begin{array}{l}\text { Trial ID } \\
\text { (References) }\end{array}$ & Treatment & Phase & $\begin{array}{l}\text { Enrollment } \\
\text { (N) }\end{array}$ & Trial Title \\
\hline NCT04270409 & $\begin{array}{l}(\text { Len }+ \text { Dex }) \\
\quad \pm \text { Isa }\end{array}$ & III & 323 & $\begin{array}{l}\text { A phase III randomized, open label, multicenter study of isatuximab in } \\
\text { combination with lenalidomide and dexamethasone versus lenalidomide and } \\
\text { dexamethasone in patients with high-risk smoldering MM }\end{array}$ \\
\hline NCT02990338 & $\begin{array}{c}(\text { Pom }+ \\
\text { Dex }) \pm \text { Isa }\end{array}$ & III & 307 & $\begin{array}{l}\text { A phase III randomized, open-label, multicenter study comparing isatuximab in } \\
\text { combination with pomalidomide and low-dose dexamethasone versus } \\
\text { pomalidomide and low-dose dexamethasone in patients with RRMM ICARIA- } \\
\text { MM }\end{array}$ \\
\hline NCT03275285 54,60 & $\begin{array}{l}(\text { Isa }+ \text { Carf } \\
+ \text { Dex) vs } \\
\text { (Carf }+ \\
\text { Dex) }\end{array}$ & III & 302 & $\begin{array}{l}\text { Randomized, open label, multicenter study assessing the clinical benefit of } \\
\text { isatuximab combined with carfilzomib and dexamethasone versus carfilzomib } \\
\text { with dexamethasone in patients with RRMM previously treated with I to } 3 \\
\text { prior lines (IKEMA) }\end{array}$ \\
\hline NCT025I $4668^{61}$ & Isa & 1 & 55 & $\begin{array}{l}\text { An open-label, dose-escalation and multi-center study to evaluate the safety, } \\
\text { pharmacokinetics and efficacy of isatuximab in patients with RRMM }\end{array}$ \\
\hline NCT02960555 & Isa & II & 61 & Phase II single arm trial of isatuximab in patients with high risk smoldering MM \\
\hline NCT02332850 60,63 & $\begin{array}{l}\text { Isa }+ \text { Carf }+ \\
\text { Dex }\end{array}$ & I & 89 & $\begin{array}{l}\text { A multi-arm phase lb study of isatuximab in combination with standard } \\
\text { carfilzomib, and high-dose weekly carfilzomib and dexamethasone for the } \\
\text { treatment of RRMM }\end{array}$ \\
\hline NCT03319667 & $\begin{array}{l}\text { (Len }+ \text { Bort } \\
+ \text { Dex }) \pm \\
\quad \text { Isa }\end{array}$ & III & 475 & $\begin{array}{l}\text { A phase III randomized, open-label, multicenter study assessing the clinical } \\
\text { benefit of isatuximab in combination with bortezomib, lenalidomide and } \\
\text { dexamethasone versus bortezomib, lenalidomide and dexamethasone in } \\
\text { patients with newly diagnosed MM not eligible for transplant (IMROZ) }\end{array}$ \\
\hline NCT01749969 65,66 & $\begin{array}{l}\text { Isa }+ \text { Len }+ \\
\text { Dex }\end{array}$ & I & 60 & $\begin{array}{l}\text { A phase lb study of isatuximab in combination with lenalidomide and } \\
\text { dexamethasone for the treatment of RRMM }\end{array}$ \\
\hline NCT02283775 & $\begin{array}{l}\text { Isa }+ \text { Pom }+ \\
\text { Dex }\end{array}$ & 1 & 89 & $\begin{array}{l}\text { A phase lb study of isatuximab in combination with pomalidomide and } \\
\text { dexamethasone for the treatment of RRMM (PomdeSAR) }\end{array}$ \\
\hline
\end{tabular}

Abbreviations: Bort, bortezomib; Carf, carfilzomib; Dex, dexamethasone; Isa, isatuximab; Len, lenalidomide; Pom, pomalidomide. 


\section{SLAMF7 as a Monoclonal Antibody Target}

Members of the signaling lymphocytic activation molecule family (SLAMF) of proteins are highly expressed on the surface of plasma cells, both normal and from MM patients, as well as natural killer (NK) cells, but not on other blood cells or other body tissues. While mAbs directed against SLAMF3 and SLAMF6 (SGN-CD48A and azintuxizumab vedotin/ABBV-838, respectively) have proven unsuccessful in early stages of myeloma-directed clinical trials, SLAMF7 (CS1 or CD319) has emerged as a major target in the fight against MM. The antimyeloma activity of SLAMF7-targeted antibodies results from their ability to initiate ADCC toward myeloma cells following activation and engagement of NK cells. ${ }^{71-74}$ The foremost anti-SLAMF7 mAb is elotuzumab, a humanized IgG1k antibody.

In 2015, shortly following its action regarding daratumumab, elotuzumab was approved for treatment of MM in the US. Approval was granted for use in combination with lenalidomide and dexamethasone in MM patients who had already received one to three prior therapies. ${ }^{75}$ Unlike daratumumab, elotuzumab lacks single-agent activity. ${ }^{76}$ The FDA's action was prompted by the favorable results of the ELOQUENT-2 trial (NCT01239797) that included 646 RRMM patients, randomly assigned to receive the $\mathrm{mAb}$ combined with dexamethasone with or without lenalidomide. A progression-free survival (PFS) of 19.4 months for the elotuzumab group plus an overall response rate (ORR) of $68 \%$ after one year and $41 \%$ at two years compared very favorably to the 14.9 months and $57 \%$ and $27 \%$ exhibited by the control cohort. ${ }^{77}$ A four-year follow-up provided further confirmation of the result of this trial. ${ }^{78}$ The ELOQUENT-3 trial (NCT02654132), which investigated the use of elotuzumab-dexamethasone plus pomalidomide in RRMM patients refractory to both lenalidomide and a proteasome blocker, resulted in formal approval of this triplet therapy in patients who had received at least two prior therapies that included these two agents. ${ }^{79}$ Trials with thalidomide, another immunomodulator, have proven inferior in RRMM patients compared to those obtained with lenalidomide or pomalidomide. ${ }^{80}$ Moreover, additional trials combining elotuzumab with proteasome inhibitors - bortezomib ${ }^{80-82}$ or carfilzomib $^{83}$ - have, thus far, failed to generate the level of favorable outcomes of the scale produced by immunomodulator combinations. A list of selected trials that include elotuzumab is presented in Table 3.

\section{Antibody-Drug Conjugates}

Antibody-drug conjugates (ADCs) are drugs designed to kill tumor cells by chemically linking a cytotoxin (or, in some cases a radionuclide) to an antibody which targets either a tumor-specific antigen (TSA) or tumor-associated antigen (TAA). Over the past several years a number of ADCs have been developed to treat an array of malignancies, including breast cancer, acute leukemias, and Hodgkin's lymphoma.

ADC construction is based on three components a mAb with high specificity for a particular TAA or TSA, a small cytotoxic molecule (the payload), and a linker designed to attach the payload to the mAb. Internalization of the ADC by endocytosis followed by lysosomal processing releases the cytotoxin to initiate apoptosis of the tumor cell. Fully human or humanized IgG1 antibodies often are preferred in these constructs due to their potent ability to activate ADCC and ADCP through Fc $\gamma$ RIIIa binding to NK cells. ${ }^{97}$ Removal of fucosyl groups (afucosylation) from the $\mathrm{N}$-linked biantennary complex oligosaccharides in the antibody's Fc region further improves binding to FcyIIIa receptors on NK cells, resulting in enhanced ADCC. ${ }^{98}$

B-cell maturation antigen (BCMA, CD269, TNFRSF17) is a tumor necrosis factor (TNF) family member that acts as a ligand for BAFF (B-cell activating factor) and APRIL (a proliferation-inducing ligand), two cytokines that play key roles in myeloma cell viability and proliferation. ${ }^{99}$ While inhibitors of BAFF and APRIL have fared poorly in MM trials, ${ }^{100,101}$ BCMA, which was first discovered nearly thirty years ago, ${ }^{102-105}$ has come to the fore in recent years as an attractive target in the search for new drugs to treat MM. ${ }^{106-109}$ As its name implies, expression of this 184-amino acid glycoprotein is a key factor in the normal maturation and differentiation of B-cells into fully functional plasmacytes. Both BCMA and its mRNA, whose presence is almost exclusively confined to plasma cells, are known to be consistently overexpressed during malignant transformation to MM, driving tumor cell growth, survival, and drug resistance as determined in both cell lines and patient samples. Furthermore, much evidence suggests that measurements of membrane bound BCMA may serve not only as a biomarker for MM diagnosis and prognosis, but also as a predictor of treatment response. ${ }^{110}$

Cleavage of the extracellular domain from membranebound BCMA by the action of gamma-secretase results in release of soluble BCMA (sBCMA) into the plasma; ${ }^{11}$ elevation of sBCMA blood levels in MM patients has been 
Table 3 Selected Trials of Elotuzumab in Multiple Myeloma (MM)

\begin{tabular}{|c|c|c|c|c|}
\hline Trial ID (References) & Treatment & Phase & $\begin{array}{l}\text { Enrollment } \\
\qquad(\mathbf{N})\end{array}$ & Trial Title \\
\hline NCT027I8833 & $\begin{array}{l}\text { Elo }+ \text { Pom }+ \text { Bort }+ \\
\text { Dex }\end{array}$ & ॥ & 52 & $\begin{array}{l}\text { A phase II study of elotuzumab in combination with } \\
\text { pomalidomide, bortezomib, and dexamethasone in RRMM }\end{array}$ \\
\hline NCT02159365 ${ }^{85}$ & Elo + Len + Dex & II & 84 & $\begin{array}{l}\text { A phase II single arm study of safety of elotuzumab administered } \\
\text { over approximately } 60 \text { minutes in combination with lenalidomide } \\
\text { and dexamethasone for newly diagnosed or RRMM patients }\end{array}$ \\
\hline NCTOI $478048^{86}$ & $($ Bort + Dex $) \pm$ Elo & II & 185 & $\begin{array}{l}\text { A Phase II, randomized study of bortezomib/dexamethasone with } \\
\text { or without elotuzumab in subjects with RRMM }\end{array}$ \\
\hline NCT0I $44 \mid 973^{87,88}$ & Elo & II & 41 & $\begin{array}{l}\text { A phase II biomarker study of elotuzumab monotherapy to assess } \\
\text { the association between NK cell status and efficacy in high risk } \\
\text { smoldering myeloma }\end{array}$ \\
\hline NCT02654I3279 & $($ Pom + Dex $) \pm$ Elo & II & 157 & $\begin{array}{l}\text { An open label, randomized phase II trial of pomalidomide and } \\
\text { dexamethasone with or without elotuzumab in RRMM } \\
\text { (ELOQUENT-3) }\end{array}$ \\
\hline NCT02495922 ${ }^{89}$ & $\begin{array}{l}(\text { Len }+ \text { Bort }+ \text { Dex }) \\
\quad \pm \text { Elo }\end{array}$ & III & 564 & $\begin{array}{l}\text { A randomized phase III trial on the effect of elotuzumab in VRd } \\
\text { induction /consolidation and lenalidomide maintenance in patients } \\
\text { with newly diagnosed MM }\end{array}$ \\
\hline NCT0। $6687 \mid 9^{81,90}$ & $\begin{array}{l}(\text { Len }+ \text { Bort }+ \text { Dex }) \\
\quad \pm \text { Elo }\end{array}$ & $\mathrm{I} / \mathrm{II}$ & 122 & $\begin{array}{l}\text { A randomized phase I/II study of optimal induction therapy of } \\
\text { bortezomib, dexamethasone, and lenalidomide with or without } \\
\text { elotuzumab for newly diagnosed high risk MM }\end{array}$ \\
\hline NCT0I $239797^{77,78,91-94}$ & $($ Len + Dex $) \pm$ Elo & III & 761 & $\begin{array}{l}\text { Phase III, randomized, open label trial of lenalidomide and } \\
\text { dexamethasone with or without elotuzumab in RRMM } \\
\text { (ELOQUENT-2) }\end{array}$ \\
\hline NCT0074256095 & Elo + Len + Dex & II & 101 & $\begin{array}{l}\text { A phase Ib/ll, multicenter, open-label, dose-escalation study of } \\
\text { elotuzumab in combination with lenalidomide and dexamethasone } \\
\text { in subjects with RRMM }\end{array}$ \\
\hline NCT0272658I ${ }^{96}$ & $\begin{array}{l}(\mathrm{Pom}+\mathrm{Niv}+\mathrm{Elo}+ \\
\text { Dex }) \text { vs (Pom }+ \text { Dex } \\
\pm \mathrm{Niv})\end{array}$ & III & 348 & $\begin{array}{l}\text { An open-label, randomized phase III trial of combinations of } \\
\text { nivolumab, pomalidomide and dexamethasone in RRMM }\end{array}$ \\
\hline
\end{tabular}

Abbreviations: Bort, bortezomib; Dex, dexamethasone; Elo, elotuzumab; Len, lenalidomide; Niv, nivolumab; Pom, pomalidomide.

correlated with inferior clinical outcomes. ${ }^{112}$ Moreover, sBCMA not only lowers the density of the target antigen but also provides a soluble decoy having the capacity to reduce the efficacy of new anti-BCMA agents currently under investigation. In an effort to mitigate this potential hurdle, a number of gamma-secretase inhibitors have been developed to enhance effectiveness of BCMA-directed therapies. ${ }^{113,114}$ Crenigacestat (LY3039478, JSMD-194) and nirogacestat are among the orally active $\gamma$-secretase inhibitors that have been included in clinical trials of antiBCMA immunotherapies.

Belantamab mafodotin (Blenrep ${ }^{\circledR}$, belamaf, GSK2857916) is an ADC in which the BCMA-targeted humanized afucosylated IgG1 antibody is coupled to the microtubule inhibitor monomethyl auristatin $\mathrm{F}$ (mafodotin, MMAF) through a non-cleavable maleimidocaproyl linker. ${ }^{115,116}$ ADCC is induced by the antibody following its binding to the BCMA receptor on the myeloma cell surface while the cytotoxic component causes cell cycle arrest at the G2/M checkpoint. ${ }^{117}$ In August 2020, belantamab mafodotin became the first ADC to receive FDA approval for MM. The endorsement was provided on an accelerated basis for use in RRMM patients who had received at least four earlier regimens, including a proteasome inhibitor, an anti-CD38 $\mathrm{mAb}$, and an immunomodulator. ${ }^{118}$ Approval was predicated on data 
from the DREAMM-2 trial (NCT03525678), which included a total of 196 RRMM patients, divided into two dosage cohorts: $2.5 \mathrm{mg} / \mathrm{kg}(\mathrm{N}=97)$ and $3.4 \mathrm{mg} / \mathrm{kg}$ $(\mathrm{N}=99)$. ORR and PFS data recorded for the two groups was $31 \%$ and 2.9 months and $34 \%$ and 4.9 months, respectively. ${ }^{119}$ Table 4 lists a number of clinical trials that include belantamab mafodotin, which are currently active or in the initial planning stages. Thrombocytopenia and anemia were among the commonly reported adverse events noted with the drug in the DREAMM-2 trial, as well as in

Table 4 Selected Trials of Belantamab Mafodotin in Multiple Myeloma (MM)

\begin{tabular}{|c|c|c|c|c|}
\hline $\begin{array}{l}\text { Trial ID } \\
\text { (References) }\end{array}$ & Treatment & Phase & $\begin{array}{l}\text { Enrollment } \\
\text { (N) }\end{array}$ & Trial Title \\
\hline NCT02064387 128 & BelMaf & I & 79 & $\begin{array}{l}\text { A phase I open-label, dose escalation study to investigate the safety, } \\
\text { pharmacokinetics, pharmacodynamics, immunogenicity and clinical activity of } \\
\text { the antibody drug conjugate GSK28579I6 in subjects with RRMM and other } \\
\text { advanced hematologic malignancies expressing BCMA (DREAMM-I) }\end{array}$ \\
\hline NCT03525678 129,130 & BelMaf & ॥ & 221 & $\begin{array}{l}\text { A phase II, open label, randomized, two-arm study to investigate the efficacy } \\
\text { and safety of two doses of the antibody drug conjugate GSK2857916 in } \\
\text { participants with MM who had } 3 \text { or more prior lines of treatment, are } \\
\text { refractory to a proteasome inhibitor and an immunomodulatory agent and } \\
\text { have failed an anti-CD38 antibody (DREAMM 2) }\end{array}$ \\
\hline NCT04162210 131 & $\begin{array}{l}\text { BelMaf vs (Pom } \\
+ \text { Dex) }\end{array}$ & III & 380 & $\begin{array}{l}\text { A phase III, open-label, randomized study to evaluate the efficacy and safety } \\
\text { of single agent belantamab mafodotin compared to pomalidomide plus low } \\
\text { dose dexamethasone in participants with RRMM (DREAMM 3) }\end{array}$ \\
\hline NCT03848845 132 & $\begin{array}{l}\text { BelMaf + } \\
\text { Pembro }\end{array}$ & $\mathrm{I} / \mathrm{II}$ & 41 & $\begin{array}{l}\text { A phase I/II single arm open-label study to explore safety and clinical activity } \\
\text { of GSK28579I6 administered in combination with pembrolizumab in subjects } \\
\text { with RRMM (DREAMM 4) }\end{array}$ \\
\hline NCT03544281 ${ }^{133,134}$ & $\begin{array}{l}\text { BelMaf + Dex } \\
+(\text { Len or Bort })\end{array}$ & $1 / I I$ & 152 & $\begin{array}{l}\text { A phase } \mathrm{I} / \mathrm{II} \text {, open-label, dose escalation and expansion study to evaluate } \\
\text { safety, tolerability, and clinical activity of GSK } 2857916 \text { administered in } \\
\text { combination with lenalidomide plus dexamethasone, or bortezomib plus } \\
\text { dexamethasone in participants with RRMM (DREAMM-6) }\end{array}$ \\
\hline NCT04246047 135 & $\begin{array}{l}\text { Bort }+ \text { Dex }+ \\
\text { (BelMaf or } \\
\text { Dara) }\end{array}$ & III & 478 & $\begin{array}{l}\text { DREAMM 7: a multicenter, open-label, randomized phase III study to evaluate } \\
\text { the efficacy and safety of the combination of belantamab mafodotin, } \\
\text { bortezomib, and dexamethasone compared with the combination of } \\
\text { daratumumab, bortezomib, and dexamethasone in participants with RRMM }\end{array}$ \\
\hline NСT04484623 136 & $\begin{array}{l}\text { Pom }+ \text { Dex }+ \\
\text { (BelMaf or } \\
\text { Bort) }\end{array}$ & III & 450 & $\begin{array}{l}\text { A phase III, multicenter, open-label, randomized study to evaluate the efficacy } \\
\text { and safety of belantamab mafodotin in combination with pomalidomide and } \\
\text { dexamethasone versus pomalidomide plus bortezomib and dexamethasone } \\
\text { in participants with RRMM (DREAMM 8) }\end{array}$ \\
\hline NCT0409II26 137 & $\begin{array}{c}\text { Bort }+ \text { Len }+ \\
\text { Dex }( \pm \text { BelMaf })\end{array}$ & 1 & 144 & $\begin{array}{l}\text { A Phase I, randomized, dose and schedule evaluation study to investigate the } \\
\text { safety, pharmacokinetics, pharmacodynamics and clinical activity of } \\
\text { belantamab mafodotin administered in combination with standard of care in } \\
\text { participants with newly diagnosed MM (DREAMM 9) }\end{array}$ \\
\hline NCT04398745 & BelMaf & I & 36 & $\begin{array}{l}\text { A phase I study to evaluate the pharmacokinetics and safety of belantamab } \\
\text { mafodotin monotherapy in participants with RRMM who have normal and } \\
\text { varying degrees of impaired renal function (DREAMM I2) }\end{array}$ \\
\hline NCT04398680 & BelMaf & I & 28 & $\begin{array}{l}\text { A phase I study to evaluate the pharmacokinetics and safety of belantamab } \\
\text { mafodotin monotherapy in participants with RRMM who have normal and } \\
\text { varying degrees of impaired hepatic function (DREAMM I3) }\end{array}$ \\
\hline
\end{tabular}

Abbreviations: BelMaf, belantamab mafodotin; Bort, bortezomib; Dara, daratumumab; Dex, dexamethasone; Len, lenalidomide; Pembro, pembrolizumab; Pom, pomalidomide. 
the earlier Phase I study. However, the toxic effect of greatest concern has been the corneal microcyst-like epithelial changes (MECs) that were observed with belantamab mafodotin as a single agent in $72 \%$ (68/95) of patients. ${ }^{120}$ Neither corticosteroid eye drops nor artificial tears appeared to mitigate this toxic reaction, whose mechanism is unknown. MECs also have been a commonly reported issue in studies of patients receiving other ADCs that employ MMAF as the cytotoxic component. ${ }^{121}$ For this reason, FDA approval was accompanied by a Boxed Warning requirement indicating that changes in the corneal epithelium may result in vision loss, blurred vision, corneal ulcers, and dry eyes. Consequently, the drug is available only under a restricted Risk Evaluation and Mitigation Strategy (REMS) program.

Another BCMA-targeted ADC that has been in a phase I trial (NCT03489525) for RRMM is MEDI2228. Although this agent had shown some early promise in terms of efficacy and toxicity, it was recently announced that the drug has been dropped by its sponsor (AstraZeneca) from further consideration for $\mathrm{MM}$. AMG 224 , an IgG1 mAb, conjugated to the microtubule inhibitor mertansine via a maleimidocaproyl-derived non-cleavable linker, has shown some encouraging results in a phase I trial (NCT02561962) in which an ORR of 23\% was reported in an initial study of 40 heavily pretreated RRMM patients. $^{122}$

Amanitin, an extremely potent inhibitor of RNA polymerase II that is produced by the deadly Amanita phalloides ("death cap") mushroom, has come to the fore recently as a cytotoxin exhibiting a novel mode of action among ADCs. One such ADC is HDP-101, comprised of an amanitin analog coupled to a BCMA-targeted antibody via a cathepsin B-cleavable linker. ${ }^{123-125}$ Based on the highly favorable results of a pre-clinical study, ${ }^{126}$ HDP101 recently (May 2021) was advanced to a phase I safetyassessment trial (NCT04879043) in RRMM patients. ${ }^{127}$

\section{T-Cell-Engaging Bi-Specific Antibodies}

T-cell-based immunotherapies have assumed major importance as viable approaches to cancer treatment, especially during the past decade. The field has been dominated particularly by two areas of research: chimeric antigen receptor (CAR) T-cell therapies and T-cell-engaging bispecific antibodies (T-BsAbs). The latter will be described in this section first while discussion of the former will be reserved for the following segment.

Based on a concept originally proposed sixty years ago by Nisonoff, ${ }^{138}$ T-BsAbs are predicated on the construction of a dual-targeting antibody whereby one arm first binds to the T-cell CD3 co-receptor while the other arm subsequently is recruited to a TAA or TSA on the targeted cancer cell. Although there are numerous variations on this concept, the basic strategy results in tethering of cytotoxic T-cells to tumor cells in order to cause cytolysis of the latter. $^{139-141}$ The destructive effects are due to the combined actions of two cytolytic-initiating proteins released by cytotoxic T-cells: perforin, which generates transmembrane pores in the tumor cells and granzyme B, which navigates through the formed pores to initiate apoptotic death of the tumor cell. ${ }^{142,143}$ The bi-specific antibody approach affords certain advantages by obviating the need for antibody-presenting cells, co-stimulatory molecules, or interaction between an antigen and a major histocompatibility complex (MHC) molecule. In addition, the persistent T-cell activation enables polyclonal expansion of $\mathrm{T}$ memory cells. Furthermore, such constructs remove any requirement for ex vivo T-cell manipulation, thus making "off the shelf" products feasible. Modification of each arm's relative binding affinity for its respective target permits fine-tuning of each construct's therapeutically relevant properties to optimize activity and biopharmaceutic parameters. ${ }^{144-147}$

The first, and thus far only, successful application of the bi-specific antibody concept to cancer immunotherapy has been the result of a collaboration between Amgen and Micromet that developed the $\mathrm{BiTE}^{\circledR}$ (Bi-specific T-cell Engager) platform in which the crosslink between T-cell CD3 co-receptor and tumor cell lymphocyte antigen CD19, is provided by tandem single-chain variable fragments (scFvs). The resulting product, blinatumomab (Blincyto $^{\circledR}$ ), was granted accelerated FDA approval in 2014 for use in B-cell precursor acute lymphocytic leukemia (B-cell ALL). ${ }^{148,149}$ However, extension of the blinatumomab success to RRMM has not been as favorable in terms of employing CD19 as a bi-specific binding partner. This may be related to the observation that CD19 expression by B-cells is known to progressively decrease throughout their development from the pre-B-cell stage to differentiation into plasma cells and even further during transformation into myeloma cells. ${ }^{150,151}$ This increasing loss of CD19 has been proposed as a contributing factor in 
myeloma cell proliferation, which would appear to preclude realization of benefits of anti-CD19 therapy in MM. However, the recent finding of CD19 at very low levels on $\mathrm{MM}$ cells by super-resolution microscopy, ${ }^{152}$ although undetectable by conventional flow cytometry, may yet make CD19 an intriguing target for immunotherapy of MM. A single phase I RRMM-based trial (NCT03173430) of blinatumomab, combined with ASCT, unfortunately had to be terminated at an early stage because of "slow patient accrual".

Although utilization of CD19 as a suitable binding partner for bi-specific antibodies in MM appears to be stymied at this point, BCMA, as in the ADC arena, has assumed a major role in BiTE $^{\circledR}$ research. ${ }^{153-156}$ One such agent, AMG 420 (BI836909) demonstrated favorable results in a phase I doseescalation trial (NCT02514239), achieving a 31\% ORR in 42 RRMM patients, including $70 \%$ (7/10) in those who received the maximum tolerated dose (400 $\mathrm{mg}$ /day). Infections and polyneuropathy were the most serious adverse events related to treatment. Cytokine release syndrome (CRS) (see below), primarily grade 1 , was reported in $38 \%$ of patients in the study. ${ }^{157}$ Pavurutamab (AMG 701), another BiTE ${ }^{\circledR}$ product from Amgen, with an extended serum half-life compared to AMG 420, is the subject of a phase I study (NCT03287908), both as monotherapy and in combination with pomalidomide; inclusion of the latter was suggested by the results of an earlier preclinical study. ${ }^{158}$ Initial results from 75 heavily pretreated RRMM patients indicated that monotherapy with pavurutamab demonstrated encouraging activity and a manageable safety profile. ${ }^{159} \mathrm{~A}$ recent press release revealed that this study has been paused in order to "discuss protocol modifications to optimize safety monitoring and mitigation with the FDA". ${ }^{160}$

Additional BCMAxCD3 bi-specific and related constructs that currently are in phase I trials for RRMM include the following: ${ }^{154,161}$

- REGN5458 (NCT03761108) and REGN5459 (NCT04083534), under development by a Regeneron/Sanofi partnership. Thus far, both preclinical and preliminary patient data have been reported only for the former. ${ }^{162,163}$

- Teclistamab (JNJ-64007957), which has been shown to be well tolerated in a monkey model ${ }^{164}$ and has demonstrated other favorable characteristics in vitro, ${ }^{165}$ has been included in a dose-escalation study (NCT03145181) in which an ORR of 78\% (7/9) was reported for patients receiving the highest dose while exhibiting a manageable safety profile. ${ }^{166-168}$

- Elranatamab (PF-06863135; PF-3135), derived from hinge-mutation engineering of an IgG2a backbone, ${ }^{169}$ has been the subject of a safety and efficacy investigation (NCT03269136) for which preliminary results have been reported. ${ }^{170-173}$ The drug's advancement to a phase II trial recently was announced. ${ }^{174}$

- CC-93269, a trivalent T-cell engager in which one arm binds to $\mathrm{CD} 3 \varepsilon$ while the other two arms attach bivalently to BCMA, exhibited promise in one cohort of heavily pretreated RRMM patients who attained an ORR of $83 \%(10 / 12)$ at the highest dose level (6 mg.) (NCT03486067). ${ }^{175}$

- TNB-383B, a collaborative effort between AbbVie and Tenebio, is comprised of a single light chain domain and two variable heavy chains in a BCMAxCD3 format. Its strong T-cell activation kinetics and low-affinity anti-CD3 $\varepsilon$ arm are said to be responsible for the reduced level of cytokine release without diminishing cytotoxicity associated with the product. ${ }^{176-178}$ An ORR of 52\% (12/23) at well-tolerated doses recently was reported in a preliminary study (NCT03933735) of TNB-383B, which received FDA designation as an Orphan Drug in 2019. ${ }^{179,180}$

- HPN217, developed by Harpoon Therapeutics, is another example of a tri-specific engager. In this case, the molecule consists of three binding domains in a single chain: a BCMA-binding component at the $\mathrm{N}$-terminus, a CD3e T-cell receptor (TCR) binding domain at the $\mathrm{C}$-terminus, and a central human serum albumin-binding portion. This product's smaller size and flexibility are thought to account for its prolonged half-life. ${ }^{181} \mathrm{~A}$ recent report outlined the design of a phase I/II investigation of HPN217 in RRMM patients. ${ }^{182}$

Targeting TAA or TSA receptors on NK cells represents an alternative strategy for development of BCMAtargeted bi-specifics. As with cytotoxic T-cells, NK cells release granzyme and perforin while they also express certain apoptosis-inducing ligands. ${ }^{183,184}$ A tri-specific engager that binds BCMA and CD200 on myeloma cells and CD16A on NK cells is one such example. ${ }^{106,185}$ Another is RO7297089 (AFM26), a bi-specific designed to engage myeloma cell BCMA and NK CD16A, which 
exhibited an acceptable safety profile in preclinical work. $^{186}$ An additional example is Compass Therapeutics' bi-specific CTX-4419 in which the binding partners are myeloma cell BCMA and NK cell p30, demonstrating that although NK CD16A binding may enhance cytotoxicity, it may not be a requirement for antimyeloma activity. Some promise has been shown in preclinical work on CTX-4419. ${ }^{187}$ Similar properties have been noted for CTX-8573, another Compass entry into the anti-myeloma multi-specific antibody arena. ${ }^{188}$

Myeloma surface antigens other than BCMA also have served as targets for bi-specific antibody development. A major candidate in this area is cevostamab (BFCR4350A; RO7187797), designed to bind T-cell CD3 with FcRH5, ${ }^{189}$ expressed on virtually all myeloma cells and now the subject of two clinical trials for RRMM (NCT04910568 and NCT03275103). ${ }^{190,191}$ Among the other non-BCMA directed constructs also under investigation are the $\mathrm{CD} 3 \times \mathrm{CD} 38 \mathrm{mAb}$ found in GBR 1342 (NCT03309111), ${ }^{192}$ a CD3xCD20 bispecific, ${ }^{193,194}$ and talquetamab (JNJ-64407564), a bi-specific construct designed to link CD3 to G-protein-coupled receptor class $\mathrm{C}$ group 5 member D (GPRC5D), a TAA expressed at high levels in malignant plasma cells but limited to hair follicles and lung tissue in healthy individuals. ${ }^{168,195-197}$ An initial phase I evaluation (NCT03399799) of talquetamab monotherapy reported ORRs of $78 \%(14 / 18)$ when given iv and $67 \%$ (8/ 12) when used sc. ${ }^{196}$ Also under study are combinations of subcutaneous daratumumab (with or without pomalidomide)

Table 5 Selected Trials of T-Cell Engaging Bi-Specific Antibodies in Multiple Myeloma (MM)

\begin{tabular}{|c|c|c|c|c|}
\hline $\begin{array}{l}\text { Trial ID } \\
\text { (References) }\end{array}$ & Treatment & Phase & $\begin{array}{l}\text { Enrollment } \\
\qquad(\mathbf{N})\end{array}$ & Trial Title \\
\hline NCT025I4239198 & AMG 420 & I & 43 & $\begin{array}{l}\text { An open label, phase I, dose escalation study to characterize the safety, } \\
\text { tolerability, pharmacokinetics, and pharmacodynamics of intravenous } \\
\text { doses of AMG } 420 \text { in RRMM patients }\end{array}$ \\
\hline NCT03287908 159,199 & $\begin{array}{l}\text { AMG 70I alone vs } \\
\text { (AMG 70I + Pom } \pm \\
\text { Dex) }\end{array}$ & $\mathrm{I} / \mathrm{II}$ & 408 & $\begin{array}{l}\text { A phase I/II open-label study evaluating the safety, tolerability, } \\
\text { pharmacokinetics, pharmacodynamics, and efficacy of pavurutamab } \\
\text { (AMG 70I) monotherapy, or in combination with pomalidomide, with } \\
\text { and without dexamethasone in subjects with RRMM (ParadigMM-IB) }\end{array}$ \\
\hline NCT0376II08 162,200 & REGN5458 & $\mathrm{I} / \mathrm{II}$ & 200 & Phase I/II FIH study of REGN5458 in patients with RRMM \\
\hline NCT03|45|8| 167 & Tecl & I & 204 & $\begin{array}{l}\text { A phase I, first-in-human, open-label, dose escalation study of } \\
\text { teclistamab in subjects with RRMM }\end{array}$ \\
\hline NCT04649359 & Elra & II & 150 & $\begin{array}{l}\text { MAGNETISMM-3 an open-label, multicenter, non-randomized phase II } \\
\text { study of elranatamab (PF-06863/35) monotherapy in participants with } \\
\text { MM who are refractory to at least one proteasome inhibitor, one } \\
\text { immunomodulatory drug and one anti-CD38 antibody }\end{array}$ \\
\hline NCT03486067 & CC-93269 & I & 175 & $\begin{array}{l}\text { A phase I, open-label, dose finding study of CC- } 93269 \text {, a BCMA X CD3 } \\
T \text { cell engaging antibody, in subjects with RRMM }\end{array}$ \\
\hline NCT03933735 180 & TNB-383B & I & 133 & $\begin{array}{l}\text { A multicenter, phase I, open-label, dose-escalation and expansion study } \\
\text { of TNB-383B, a bi-specific antibody targeting BCMA in subjects with } \\
\text { RRMM }\end{array}$ \\
\hline NCT04I84050 & HPN2I7 & $\mathrm{I} / \mathrm{II}$ & 70 & $\begin{array}{l}\text { A phase I/II open-label, multicenter, dose escalation and dose expansion } \\
\text { study of the safety, tolerability, and pharmacokinetics of HPN2I7 in } \\
\text { patients with RRMM }\end{array}$ \\
\hline NCT04434469 & RO7297089 & I & 80 & $\begin{array}{l}\text { An open-label, multicenter, phase I trial evaluating the safety and } \\
\text { pharmacokinetics of escalating doses of RO7297089 in patients with } \\
\text { RRMM }\end{array}$ \\
\hline NСT03399799196 & Talq & I & 245 & $\begin{array}{l}\text { A phase I, first-in-human, open-label, dose escalation study of } \\
\text { talquetamab in subjects with RRMM }\end{array}$ \\
\hline
\end{tabular}

Abbreviations: Dex, dexamethasone; Elra, elranatamab; Len, lenalidomide; Pom, pomalidomide; Talq, talquetamab; Tecl, teclistamab. 
plus either talquetamab or the above-noted teclistamab (NCT04108195).

A list of selected clinical trials that include T-cell engaging bi-specific antibodies is shown in Table 5.

\section{Chimeric Antigen Receptor (CAR) T-Cells}

Over the past decade, chimeric antigen receptor (CAR) T-cell therapy has risen to a place of prominence as a viable immunotherapeutic approach to cancer treatment. $^{201,202}$ As a form of adoptive cell transfer (ACT), this strategy endeavors to genetically modify a patient's own cytotoxic T-cells to enable them to attack and kill a specific type of malignant cell. By employing recombinant DNA technology a viral vector is constructed so as to enable eventual expression of a chimeric receptor designed to attach to a TAA or TSA found on the targeted cancer cell. Reinfusion of the engineered T-cells back into the patient results in T-cell engagement with the targeted malignant cells leading to their death. The technique has been most successfully applied to the treatment of hematological cancers, particularly B-cell malignancies, targeting CD19 although such has not been the case when applied to MM for reasons described earlier. For example, a trial of the anti-CD19 CAR tisagenlecleucel combined with ASCT only resulted in a poor clinical benefit in a cohort of ten MM subjects (NCT02135406). ${ }^{203}$

The attainment of durable remissions with anti-CD19 CAR T-cells initially proved difficult even though ORRs in excess of $80 \%$ were seen in some early studies. ${ }^{204-207}$ The solution to this conundrum eventually was revealed when the value of adding lymphodepletion to the pre-ACT regimen became clear. The benefits of lymphodepletion, usually consisting of combined cyclophosphamide and fludarabine, were demonstrated in several CAR T-cellbased trials by reports of enhanced T-cell persistence and expansion, as well as clinical outcomes. ${ }^{208}$ Although the mechanism underlying the improved efficacy associated with lymphodepletion remains obscure, several possibilities have been proposed, including elimination of homeostatic cytokine sinks for interleukins-2, -7 , and $-15,{ }^{209}$ greater levels of monocyte chemoattract protein-1 (MCP$1),{ }^{210}$ and downregulation of tumor cell indoleamine 2,3-dioxygenase (IDO) ${ }^{211}$ to block formation of tryptophan-derived metabolites known to inhibit T-cell activity and induce tolerance to tumor antigens. ${ }^{212}$ Parenthetically, it is noteworthy that linrodostat (BMS-986205), ${ }^{213}$ an oral irreversible inhibitor of IDO1, has been included in a CAR T-cell-based MM trial (NCT04855136) that was started in April 2021.

Just as seen above with bi- and multi-specific antibodies, BCMA has taken its place as the major TSA of interest in anti-myeloma CAR T-cell research. ${ }^{155,214}$ Several of the anti-BCMA constructs of consequence are described below, and Table 6 lists several of the currently active myeloma-based anti-BCMA CAR T-cell trials.

The first clinical trial (NCT02215967) of an antiBCMA CAR T-cell construct utilized a lentivirus engineered paradigm in which the anti-BCMA scFv was linked in series to a $\mathrm{CD} 8$ hinge, a transmembrane region, a $\mathrm{CD} 28$ co-stimulatory domain, and $\mathrm{CD} 3 \zeta$ as the T-cell activator. ${ }^{215}$ Data reported for 16 RRMM patients in the study (median of 9.5 lines of prior therapy) showed a median PFS of 31 weeks and an ORR of $81 \%$ at the highest dose used $\left(9 \times 10^{6}\right.$ T-cells per $\left.\mathrm{kg}\right){ }^{216}$ This encouraging result led to a phased series of KarMAa trials of Bluebirdbio's idecabtagene vicleucel (Abecma ${ }^{\circledR}$; bb2121; ide-cel), whose structure included an antiBCMA scFv linked to CD137 (4-1BB) co-stimulatory and $\mathrm{CD} 3 \zeta$ signaling domains. ${ }^{217}$ The product was approved by the FDA in March 2021 for RRMM 218 based on the results of a pivotal phase II trial (NCT03361748; KarMAa-1) that incorporated 128 RRMM patients who had failed at least three previous regimens, including a proteasome inhibitor, an immunomodulator, and an anti-CD38 mAb. An ORR of 73\% (94/ 128) was attained and one-third (42/128) experienced complete responses or better. The median PFS was 13.3 months. CRS was the most common non-hematologic adverse effect, being found in $84 \%$ of treated subjects with $5 \%$ experiencing grade 3 or 4 . Neurotoxicity developed in $23(18 \%)$ patients - four in grade 3 and none in grade $4 .^{219}$ Bluebirdbio's next generation entry into the field, bb21217, employs the same lentiviral design as its predecessor with the addition during ex vivo culture of an extra phosphoinositide-3-kinase (PI3K) inhibitor domain (bb007). This modification significantly enhances CAR T-cell-based immunotherapy by enriching the product's population of memory-like T-cells to enhance T-cell durability and potency. ${ }^{220}$ The drug was the subject of two recent reports of an ongoing dose-escalation study (NCT03274219) of 44 RRMM patients. Confirmed responses were noted in $24(55 \%)$ patients with CRS and neurotoxicity observed in $67 \%$ and $10 \%$, respectively. Preliminary data indicated a positive correlation between 
Table 6 Selected Trials of CAR T-Cells in Multiple Myeloma (MM)

\begin{tabular}{|c|c|c|c|c|}
\hline Trial ID (References) & Treatment & Phase & $\begin{array}{l}\text { Enrollment } \\
\text { (N) }\end{array}$ & Trial Title \\
\hline NCT03361748 219,271 & Ide-cel & II & 149 & $\begin{array}{l}\text { A phase II, multicenter study to determine the efficacy and safety of } \\
\text { ide-cel in subjects with RRMM (KarMMa) }\end{array}$ \\
\hline NCT0360I078 & Ide-cel & II & 181 & $\begin{array}{l}\text { A phase II, multicohort, open-label, multicenter study to evaluate } \\
\text { the efficacy and safety of ide-cel in subjects with RRMM and in } \\
\text { subjects with clinical high-risk MM (KarMMa-2) }\end{array}$ \\
\hline NCT0365II 28 & $\begin{array}{l}\text { Ide-cel vs } 5 \text { different } \\
\text { standard of care } \\
\text { regimens }\end{array}$ & III & 381 & $\begin{array}{l}\text { A phase III, multicenter, randomized, open-label study to compare } \\
\text { the efficacy and safety of ide-cel vs standard regimens in subjects } \\
\text { with RRMM (KarMMa-3) }\end{array}$ \\
\hline NCT032742I $9^{221,222,272}$ & $b b 21217$ & I & 72 & A phase I study of bb21217 in RRMM \\
\hline NCT03090659223-225 & Cilta-cel & $\mathrm{I} / \mathrm{II}$ & 100 & A clinical study of cilta-cel in treating RRMM \\
\hline NCT03548207 226,273 & Cilta-cel & $\mathrm{I} / \mathrm{II}$ & 126 & $\begin{array}{l}\text { A phase Ib-II, open-Label study of cilta-cel, a CAR-T therapy } \\
\text { directed against BCMA, in subjects with RRMM (CARTITUDE-I) }\end{array}$ \\
\hline NCT04I33636 228 & Cilta-cel & $\|$ & 160 & $\begin{array}{l}\text { A phase II, multicohort open-label study of cilta-cel, a CAR-T } \\
\text { therapy directed against BCMA in subjects with MM (CARTITUDE- } \\
\text { 2) }\end{array}$ \\
\hline NCT03288493232 & $\begin{array}{l}\text { P-BCMA-IOI + } \\
\text { Rimiducid }\end{array}$ & $\mathrm{I} / \mathrm{II}$ & 220 & $\begin{array}{l}\text { Open-label, multicenter, phase I study to assess the safety of } \\
\text { P-BCMA-I0I in subjects with RRMM followed by a Phase } 2 \\
\text { assessment of response and safety (PRIME) }\end{array}$ \\
\hline NCT039I5I84 238 & Zevo-cel & 1 & 70 & $\begin{array}{l}\text { Open label, multi-center, phase lb/ll clinical trial to evaluate the } \\
\text { safety and efficacy of autologous zevo-cel in patients with RRMM } \\
\text { (LUMMICAR 2) }\end{array}$ \\
\hline
\end{tabular}

Abbreviations: Cilta-cel, ciltacabtagene autoleucel; Ide-cel, idecabtagene vicleucel; Zevo-cel, zevorcabtagene autoleucel.

the presence of memory-associated T-cell markers and peak expansion and duration of response, providing some tentative support for the mechanistic hypothesis underlying the product's design. ${ }^{21,222}$

Johnson and Johnson's contribution to this arena is ciltacabtagene autoleucel (JNJ-68284528; JNJ-4528; LCARB38M; cilta-cel), which differs from other BCMA-targeted T-cell therapies by being directed against two BCMA epitopes (VH1 and VH2), a feature which improves affinity for BCMA-expressing cells. The phase I LEGEND-2 study (NCT03090659) of this product was conducted on 57 patients who showed an ORR of $88 \%$ and PFS of 15 months. There was evidence of CRS, primarily grades 1 or 2 in $83 \%$ of trial subjects. ${ }^{223-225}$ Reported results from 97 RRMM patients (median of 6 prior lines of therapy) in the CARTITUDE-1 phase Ib/II trial (NCT03548207) were similar (97\% ORR, CRS 95\%) to those seen in the LEGEND-2 study. ${ }^{226}$ As a result of data from the LEGEND-2 and CARTITUDE-1 studies, in 2019 this drug was accorded PRIME status by the European Medicines Agency (EMA) and was designated a Breakthrough Therapy and subsequently granted priority review by the FDA. ${ }^{227}$ Two additional studies of the efficacy of ciltacabtagene autoleucel in RRMM currently are in progress: CARTITUDE-2 (NCT04133636) and CARTITUDE-4 (NCT04181827). Recently reported data from the former trial (phase II) indicated deep and early responses with a single infusion. ${ }^{228}$ The latter is a phase III comparison with two standard myeloma triplet therapies; no results have been reported as yet from this trial.

P-BCMA-101, a fully humanized anti-BCMA CAR T-cell product from Poseida Therapeutics, contains a CD3 $\zeta$ / 4-1BB signaling domain fused to a non-immunoglobulin Centyrin $^{\circledR}$ scaffold. Such constructs generally are smaller than those patterned after immunoglobulins and offer advantages of higher binding affinities, improved stability, reduced immunogenicity, and lower production costs. Instead of using a viral vector in the manufacturing process, P-BCMA-101 employs proprietary transposon-based technology (piggy-BAC $\left.{ }^{\circledR}\right){ }^{229}$ The process has been shown in preclinical work to yield a preponderance of $\mathrm{T}$ stem cell 
memory cells (Tscm), offering the potential for improved therapeutic longevity. ${ }^{230}$ The product also is noteworthy for the inclusion in its design of a truncated caspase 9 domain as a safety switch. Rimiducid, a caspase 9 dimerizing agent, can be administered to initiate apoptosis if patient safety is threatened. $^{231}$ P-BCMA-101 has been the subject of a phase I trial (NCT03288493; PRIME) in heavily pretreated RRMM patients. An ORR of $57 \%$ after a single administration recently was reported for a cohort of 34 evaluated subjects in the study. CRS, one in grade 3, was observed in 17\% of the patients. A possible case of neurotoxicity also was reported. $^{232}$ A long-term (15 years) follow-up study (NCT03741127) has been initiated to explore in-depth issues of this product's efficacy and toxicity.

Orvacabtagene autoleucel (orva-cel; JCARH125) and FCARH143 are two similar fully human svFv bicistronic CARs that incorporate a 4-1BB co-stimulatory domain and use a lentiviral vector although they differ in the method of production. ${ }^{233,234}$ Initial results of a trial (NCT03430011) of orva-cel in 51 RRMM patients reported an ORR of $91 \%$ while exhibiting a manageable safety profile. ${ }^{234,235}$

Zevorcabtagene autoleucel (zevo-cel; CT053) and CT103A are two BCMA-targeted CAR T-cell products under development by CARSgen Therapeutics. Both are fully human scFv constructs, containing a CD8 $\alpha$ hinge, 4$1 \mathrm{BB}$ co-stimulatory and $\mathrm{CD} 3 \zeta$ activation domains, in addition to a transmembrane component. In 2019, the FDA granted CT053 the Regenerative Medicine Advanced Therapy (RMAT) designation, based on the initial results of two trials (NCT03975907, LUMMICAR-1; and NCT03915184, LUMMICAR-2) in RRMM patients who previously had been treated with a median of four prior regimens. ${ }^{236,237}$ Updated results on 10 evaluable patients in the LUMMICAR-2 trial were presented recently and showed an ORR of $100 \%$ at a dose of $1.5-3.0 \times 10^{8}$ CAR T-cells. ${ }^{238}$ Notable early results also have been reported for the related construct CT103A, which recently has been under study in the RRMM setting in China (ChiCTR1800018137): ORR of $100 \%$ in the first 18 patients in this phase I trial. ${ }^{239,240}$ Numerous other strategic approaches to BCMA-based autologous CAR T-cell product development are represented in the array of currently active clinical trials extant in the NCI data base for MM. Included among these products are CARTddBCMA, ${ }^{241}$ C-CAR088, ${ }^{242}$ and FHVH-BCMA-T. ${ }^{243,244}$

Both CD19- and BCMA-targeted CAR T-cells have been used in combination in some trials in order to enhance efficacy, improve patient safety, and deepen clinical response. Simultaneous targeting of BCMA and SLAMF7 also is being studied. ${ }^{245}$ The dual-targeting strategy may involve co-infusion of two different pools of T-cells each expressing a different CAR or a single T-cell pool in which each T-cell expresses two different CARs (arranged either bicistronic or in tandem). ${ }^{246-249}$ For example, dual targeting has been explored in trials in newly diagnosed high-risk MM (NCT03455972) and in RRMM patients (NCT03196414). A recent review detailed the various combinations of dual-targeting strategies. ${ }^{250}$ However, meaningful patient data from trials of these dual-targeted combinations in MM have thus far been very limited. ${ }^{249,251-253}$ Future work needs to focus on the relevance of the various combinatorial approaches to the different stages of MM from newly diagnosed patients to those who fail established regimens.

Finally, preclinical data have informed trials of CAR T-cells that are directed against TSAs or TAAs other than BCMA. These targets include SLAMF7 (NCT03958656; NCT03710421), ${ }^{254,255}$ CD38 (NCT03464916), ${ }^{256}$ and CD138. ${ }^{257}$ However, only limited patient data are available on these studies. Alternatives to T-cells also have been explored in efforts to expand available options to treat RRMM. The primary contemporary candidates here are anti-BCMA-engineered NK cells; ${ }^{256,258-260}$ although SLAMF7 and CD138 also have been considered as NK cell targets in the past. ${ }^{261,262}$ Nevertheless, only a single trial (NCT03940833), involving a product from Asclepius Technology in China, is now in progress to explore the potential role of BCMA-directed NK-engineered CARs in RRMM.

Although the autologously administered CAR T-cells described above have thus far produced highly promising results, their use is not without drawbacks, such as the short-lived responses they elicit and the high risk of CRS and other dose-limiting adverse events. As a result, some CAR T-cell originators have initiated innovative programs to develop "off-the shelf" allogeneic anti-BCMA products that use T-cells from healthy donors. The pipeline of agents in this category currently is headed by two major players: ALLO-715 from Allogene Therapeutics and Precision Bioscience's PCAR269A.

ALLO-715 is manufactured using the proprietary Transcription Activator-like Effector Nuclease $\left(\right.$ TALEN $\left.^{\circledR}\right)$ system, a site-specific BCMA gene-editing technique that is hypothesized to limit the product's potential T-cell receptor-mediated immune responses, 
such as graft versus host disease (GvHD) and rapid rejection. $^{263,264}$ Recently (April 2021), ALLO-715 received the FDA's RMAT designation, ${ }^{265}$ which was based on the initial findings of the dose-escalation phase I UNIVERSAL trial (NCT04093596) of 15 heavily pre-treated RRMM patients in whom were reported an acceptable safety profile and an ORR of $33 \%$ at the dose levels tested. ${ }^{266}$ Significantly, ALLO-715 is the first anti-BCMA CAR T-cell product whose design strategy incorporates a CD20-based mimotope capable of activation by rituximab. Moreover, the UNIVERSAL trial also is noteworthy for its use of an anti-CD52 antibody, ALLO-647, as a selective lymphodepletion agent. ${ }^{267}$

PBCAR269A was developed using Arcus Bioscience's patented nuclease gene-editing platform, which is based on the homing endonuclease I-CreI scaffold. ${ }^{268,269}$ In 2020, this product received Fast-Track status from the FDA 270 and was advanced to a phase I trial for RRMM (NCT04171843).

\section{Cytokine Release Syndrome (CRS) and Neurotoxicity}

Issues related to toxicity constitute important challenges that effect immunotherapy of hematologic cancers, including the bi- and multi-specific engaging antibodies and CAR T-cell platforms described in this review. These potentially lethal toxicities, whose inability to be easily reversed may require multidisciplinary management and intensive care, often are divided into two different types: 1) a general toxicity caused by $\mathrm{T}$-cell recognition and activation against the targeted malignant cells and subsequent uncontrolled cytokine release at high levels (on-target, on-tumor toxicity) and 2) toxicity caused by cytokine release when CAR T-cells bind to the target antigen located on normal cells (on-target, off-tumor toxicity). BCMA-targeted antimyeloma products carry a low-risk of on-target, off-tumor type reactions given the virtually exclusive confinement of the antigen to plasma cells. The discussion that follows is devoted to the on-target, on-tumor types of adverse events.

The most important adverse effects that accompany ontarget, on-tumor toxicity are the cytokine release syndrome (cytokine storm; CRS) and neurotoxicity. Two terms often are used in the literature to describe the neurotoxic reactions: CAR T-cell-related encephalopathy syndrome (CRES) and immune effector cell-associated neurotoxicity syndrome (ICANS). Almost without exception, CRS and neurotoxicity are seen in varying degrees of severity in a percentage of participants in every trial of the immunotherapeutic agents described in this paper. ${ }^{274,275}$ For instance, in the CAR T-cell therapy setting meta-analysis of 15 trials $(\mathrm{N}=977)$ of anti-CD19 or anti-BCMA constructs, $62.3 \%$ (range: $11 \%$ to $100 \%$ ) experienced some degree of CRS with $18.4 \%$ (range $0.8 \%$ to $46 \%$ ) in grades 3 or $4 .^{276}$ Also, attempts to assess relative safety risks between different immunotherapeutic modalities may present complex problems. For example, meta-analysis of 8 clinical trials of anti-CD19 blinatumomab in relapsed/ refractory ALL and NHL patients $(\mathrm{N}=729)$ found that the pooled occurrence rate of CRS of grades 3 or 4 was $3.5 \%$ and that of neurotoxicity was $12 \%{ }^{277}$ These data compare with the $19 \%$ and $18 \%$ respective rates of grades 3 or higher found in a recent meta-analysis of 15 trials $(\mathrm{N}=448)$ of RR B-cell ALL patients who received C-19specific CAR T-cell therapy. ${ }^{278}$ Although tending to indicate that CRS and neurotoxicity may occur with greater frequency and severity in patients receiving CAR T-cell therapy as opposed to bi-specific antibody therapy, at least in terms of treatments targeting CD16, a number of factors, including type of malignancy under study, structure and target of the immunotherapeutic product involved, the grading scales used, and routes and timing of administration, as well as other variables may account for observed differences.

The symptoms of CRS, which generally occur in the first two weeks of therapy and resemble those of a severe inflammatory reaction, are attributed to marked increased expression and release of certain cytokines, including IL-6, IL-2R, IL-10, IFN- $\gamma$, and TNF- $\alpha .^{279,280}$ Furthermore, CRS has been effectively implicated as a major contributor to the deadly effects associated with COVID-19 infections during the current global pandemic. ${ }^{281-284}$ The IL-6 blocker tocilizumab (Actemra $^{\circledR}$ ) is the treatment of choice for cases of CRS associated with CAR T-cell therapy, FDA approval for this indication having been granted in $2017 .{ }^{285}$ However, optimal timing of tocilizumab intervention in patients at-risk for CRS remains an open question. ${ }^{286,287}$ In addition, the agent usually is administered with corticosteroid infusions although the efficacy of combining corticosteroids with tocilizumab in the management of CRS has not been tested through randomized controlled studies.

ICANS/CRES symptoms, which typically begin around 4-5 days after initiation of CART-cell therapy and usually follow the peak of CRS severity, are related to impairment of blood-brain barrier (BBB) integrity enabling CSF cytokine and lymphocyte infiltration. 
Tocilizumab is not effective in the management of neurotoxicity. Rather, glucocorticoids play the major role in its treatment although their efficacy remains undocumented. ${ }^{288-290}$

In efforts to gain better control over toxicity of CAR T-cell therapy some formats have been designed to incorporate a safety switch to enable activity curtailment through administration of a pharmacologic antagonist. ${ }^{291}$ Inclusion in the construct of a transduced CD20 receptor that can be switched "off" by administration of the CD20 blocker rituximab is one illustration of this strategy. ${ }^{292}$ Another is the incorporation of a non-functional truncated epidermal growth factor receptor (tEGFR) that can be antagonized by cetuximab. ${ }^{293,294}$ Dimerization of caspase-9 to activate apoptosis by use of the dimerizing agent rimiducid represents yet another example. ${ }^{295-297}$ The strengths and weaknesses of the various molecular safety switches employed in CAR T-cell design have been described in a recent comprehensive review of the subject. ${ }^{298}$

\section{Checkpoint Inhibitors}

Over the course of the past decade, immune checkpoint blockade has become a major strategy for immunotherapeutic drug development in the anticancer field. The approach is predicated on the interaction of specific cell surface biomarkers and their cognate ligands that enable the immune system to overcome the ability of malignant cells to evade immune surveillance and elimination. This tactic has resulted in the introduction of several antitumor mAbs designed to block these biomarker/ligand interactions. In particular, two of these biomarkers cytotoxic T-lymphocyte-associated protein-4 (CTLA-4) and the programmed death (PD) receptor thus far have been successfully applied as targets in this innovative line of attack on a variety of cancers. ${ }^{13}$ However, their utility as targets in MM has yet to be conclusively demonstrated. ${ }^{299}$ Two myeloma-based trials (NCT01592370 and NCT02681302) of the anti-CTLA-4 mAb ipilimumab combined with another checkpoint inhibitor, nivolumab, are currently ongoing. An initial report in the latter trial concluded that the combined checkpoint inhibitor therapy is safe and has potential to increase the "depth of response in patients with high-risk disease". ${ }^{300}$ Encouraging results were seen in early phase studies of PD-1 blocker pembrolizumab in MM, especially when used together with immunomodulators. $^{301}$ However, major safety issues arose concerning these pairings in phase III trials, resulting in suspension of these studies although it is noteworthy that additional combinations of pembrolizumab and other PD-1/PD-L1 blockers continue to be studied in MM as shown in Table 7. In addition to those studies shown in the table is a myeloma-based trial (NCT03111992; N=26) in which the PD-1 blocker spartalizumab was combined with an anti-IL17A mAb (CJM112) and a SMAC (second mitochondrial-derived activator of caspases) mimetic (LCL161); no results have yet appeared for this recently completed study.

In addition to CTLA-4 and PD-1/PD-L1, other checkpoints have been proposed as potential targets for immunotherapy in general or MM specifically although only limited preclinical or clinical data are available at present. ${ }^{302}$ These include killer-cell immunoglobulin-like receptors (KIR), ${ }^{259,303}$ CD47, ${ }^{304,305}$ LAG3 $3{ }^{306}$ TIGIT, ${ }^{307-309}$ and TIM$3 .^{310}$ In this connection, note should be made of an ongoing phase I/II trial (NCT04150965; N=104) in which RRMM patients receiving the anti-LAG3 relatlimab (BMS-986016) or anti-TIGIT BMS-986207 are compared to a control arm receiving a standard care regimen of elotuzumabpomalidomide-dexamethasone.

\section{Summary and Conclusions}

The therapeutic landscape of MM has shifted dramatically in the past two decades as the number of treatment options has expanded enormously and five-year survival rates, progression-free survival data, and quality of life studies continue to evidence major advances. ${ }^{313}$ The disease itself has become redefined over the years, moving away from the traditional CRAB symptoms to a risk stratification approach that aims to identify factors that can be determinant before signs and symptoms of the disease emerge, such as the progression from asymptomatic MGUS to SMM to MM. These criteria, encompassing bone marrow evaluation, immunoglobulin and free light chain analyses, cytogenetic studies, and imaging technologies, have become pillars of contemporary diagnostic evaluation, prognostication of disease course, and determination of intervention strategies. ${ }^{7}$ This optimism has been invigorated further in recent years by the advent of immunologic-based approaches to cancer treatment in general and $\mathrm{MM}$ in particular. Once considered an idealistic fantasy, cancer immunotherapy has now emerged as a validated fixture in medicine, grounded in decades of work aimed at deciphering the fundamental complex relationships between the immune system and cancer initiation, proliferation, and metastasis. This bright picture is tempered, 
Table 7 Selected Trials of Checkpoint Inhibitors in Multiple Myeloma (MM)

\begin{tabular}{|c|c|c|c|c|}
\hline $\begin{array}{l}\text { Trial ID } \\
\text { (References) }\end{array}$ & Treatment & Phase & $\begin{array}{l}\text { Enrollment } \\
\text { (N) }\end{array}$ & Trial Title \\
\hline \multicolumn{5}{|l|}{ PD-I Inhibitors } \\
\hline NCT03848845 132 & Pembro + BelMaf & $\mathrm{I} / \mathrm{II}$ & 41 & $\begin{array}{l}\text { A phase I/II single arm open-label study to explore safety and clinical } \\
\text { activity of GSK } 2857916 \text { administered in combination with } \\
\text { pembrolizumab in subjects with RRMM (DREAMM 4) }\end{array}$ \\
\hline NCT0436|85 $\left.\right|^{311}$ & Pembro + Dara & II & 33 & $\begin{array}{l}\text { Phase II Study of daratumumab-pembrolizumab for MM patients with } \geq \\
\text { three prior lines of therapy }\end{array}$ \\
\hline NCT03267888 & Pembro + Radiation & I & 24 & $\begin{array}{l}\text { Pilot study of pembrolizumab and single-fraction, low-dose, radiation } \\
\text { therapy in patients with RRMM }\end{array}$ \\
\hline NCT03292263 & $\mathrm{Niv}+\mathrm{ASCT}$ & I & 30 & Autologous stem cell transplantation with nivolumab in patients with MM \\
\hline NCT04205409 & Niv & II & 20 & $\begin{array}{l}\text { Nivolumab for relapsed or refractory disease post CAR T-cell treatment } \\
\text { in patients with hematologic malignancies, including MM }\end{array}$ \\
\hline NCT04II9336 & $\begin{array}{l}\text { Niv }+ \text { Ixazo }+ \text { Ctx }+ \\
\text { Dex }\end{array}$ & II & 50 & $\begin{array}{l}\text { A phase II study of nivolumab in combination with ixazomib, } \\
\text { cyclophosphamide, and dexamethasone in RRMM }\end{array}$ \\
\hline NCT03194867 & Isa + Cem & $1 / I 1$ & 109 & $\begin{array}{l}\text { A phase } I / I \text { study to evaluate safety, pharmacokinetics and efficacy of } \\
\text { isatuximab in combination with cemiplimab in patients with RRMM }\end{array}$ \\
\hline \multicolumn{5}{|l|}{ PD-LI Inhibitors } \\
\hline NCT02431208 312 & $\begin{array}{l}{[\text { Atz } \pm \text { Len }] \text { or }[(\text { Atz }+} \\
\text { Dara }) \pm(\text { Len or } \\
\text { Pom })]\end{array}$ & I & 85 & $\begin{array}{l}\text { A phase lb study of the safety and pharmacokinetics of atezolizumab } \\
\text { alone or in combination with an immunomodulatory drug and/or } \\
\text { daratumumab in patients with MM }\end{array}$ \\
\hline \multicolumn{5}{|l|}{ CD47 Inhibitors } \\
\hline NCT03530683 305 & TTI-622 & I & 156 & $\begin{array}{l}\text { A phase la/lb dose escalation and expansion trial of TTI- } 622 \text { in patients } \\
\text { with advanced relapsed or refractory lymphoma or myeloma }\end{array}$ \\
\hline
\end{tabular}

Abbreviations: Atz, atezolizumab; BelMaf, belantamab mafodotin; Cem, cemiplimab; Ctx, cyclophosphamide; Dara, daratumumab; Dex, dexamethasone; Isa, isatuximab; Ixazo, ixazomib; Len, lenalidomide; Niv, nivolumab; Pembro, pembrolizumab; Pom, pomalidomide.

however, by the knowledge that MM is still considered incurable regardless of the treatment measures used. The vast majority of patients who experience initial therapeutic benefits eventually become refractory to treatment modalities and experience relapse. Thus, although much progress has been made to date, the obstacles that remain must be overcome if $\mathrm{MM}$ is ever to be considered curable.

Fundamental to MM immunotherapy is the challenge to identify potential cancer-driving biomarkers that can serve as targets for therapy. At the forefront of this search are CD38, SLAMF7, and BCMA, which serve as the basis for the immunotherapies in use today. CAR T-cell-based therapies targeting BCMA have demonstrated remarkable clinical efficacy in MM with ORRs of at least $80 \%$ recorded in several clinical studies; however, response durations are short. It is now recognized that BCMA expression by myeloma cells is not as homogeneous as once thought. For example, one study found that a substantial proportion (33/85) of MM patients was BCMA-negative. ${ }^{215}$ Moreover, downregulated tumor-cell BCMA expression (antigen escape) has been reported during CAR T-cell therapy, as well as instances in which a significant fraction of initially responding patients experienced relapse despite continuing to express BCMA. ${ }^{216,246,314-317}$ Furthermore, a genome-wide geneediting CRISPR study failed to identify BCMA as being among 90 different genes essential for MM. ${ }^{318}$ Thus, combinatorial strategies using BCMA and other established targets, such as CD19, CD38, and SLAMF7 or emerging viable targets, for instance GPRC5D ${ }^{319}$ and FcRH5, ${ }^{190}$ may be of value in overcoming this issue. ${ }^{250}$ The orphan receptor GPRC5D has special appeal as 
a target in immunotherapy constructs since its expression is associated with poor prognosis in MM. ${ }^{320}$ Moreover, as a seven-pass transmembrane protein it, unlike BCMA, does not shed into the serum. In addition, expression of GPRC5D is independent of BCMA, offering the possibility of a suitable alternative target in instances of antiBCMA therapy relapse. The encouraging results, noted earlier, from myeloma-based studies of the CD3xGPRC5D bi-specific talquetamab should inform future clinical exploration of the potential of GPRC5Dtargeted CARs. Indeed, this prospect was bolstered by the finding that anti-GPRC5D CAR T-cells produced longterm survival, accompanied by disease eradication, in a myeloma mouse model resistant to BCMA-targeted therapy. $^{319}$

As CAR T-cell and T-BsAb-based immunotherapies become more widespread in the future, the role of ASCT in MM patients who are considered transplant-ineligible, generally defined as elderly (over 75 years) and/or exhibiting frailty and possible comorbidities, will need to be more clearly defined. Current treatment protocols tend to favor the combination of daratumumab, lenalidomide, and dexamethasone for newly diagnosed and RRMM patients who are ASCT ineligible. ${ }^{24}$ However, much more work lies ahead, including the need to conduct head-to-head comparison trials, in order to adequately serve this patient population. ${ }^{321}$

Going forward, much better insight into the mechanisms that drive resistance to $\mathrm{MM}$ therapy needs to be gained. A key to deepening our knowledge in this area is the bone marrow microenvironment and the role it plays in enabling malignant cells to escape immune detection. Better understanding of the mechanisms at play here will contribute to future advances that will translate into further improving immunotherapeutic outcomes for MM, including the ability to reverse bone loss. ${ }^{322}$ In addition to PFS, OS, ORR, and other measures, the ability to detect minimal residual disease (MRD) is now emerging as a key element in directing anti-myeloma therapy. Achievement of MRD negativity is increasingly viewed as a reliable prognostication marker of PFS and potential relapse. ${ }^{323}$ As technological advances enable malignant cell detection at extremely low levels, MRD measurements need to be more consistently and uniformly employed in clinical trials in order to drive therapeutic decision-making in the future.

The upsurge in knowledge gained about MM and its treatment over the past twenty years has been most impressive. The deeper understanding of the mechanisms that underlie the disease and the identification of an array of druggable biomarkers have been translated into more efficacious treatments that enable positive outcomes with greater frequency, elevating the disease to its current status as a reasonably manageable chronic condition, at least in the short-term. However, the road to a true cure for MM remains fraught with challenges which, although not insurmountable, will need to be overcome for that dream to become a future reality.

\section{Acknowledgment}

The author would like to express his gratitude to Professor George B. Corcoran, III, Chair of the Wayne State University Department of Pharmaceutical Sciences, for his 25 years of steadfast service to the Department. This manuscript is dedicated to him in honor of his unceasing support and encouragement to the author and unparalleled leadership within the University.

\section{Disclosure}

The author reports no conflicts of interest in this work.

\section{References}

1. Siegel RL, Miller KD, Fuchs HE, et al. Cancer statistics, 2021. CA Cancer J Clin. 2021;71(1):7-33. doi:10.3322/caac.21654

2. Ailawadhi S, Parikh K, Abouzaid S, et al. Racial disparities in treatment patterns and outcomes among patients with multiple myeloma: a SEER-Medicare analysis. Blood Advances. 2019;3 (20):2986-2994. doi:10.1182/bloodadvances.2019000308

3. Waxman AJ, Mink PJ, Devesa SS, et al. Racial disparities in incidence and outcome in multiple myeloma: a population-based study. Blood. 2010;116(25):5501-5506. doi:10.1182/blood-201007-298760

4. Kyle RA, Therneau TM, Rajkumar SV, et al. A long-term study of prognosis in monoclonal gammopathy of undetermined significance. $N$ Engl J Med. 2002;346(8):564-569. doi:10.1056/ NEJMoa01133202

5. Yavorkovsky LL. Smoldering multiple myeloma 40 years later: a story of unintended disease. Expert Rev Hematol. 2021;14 (2):149-153. doi:10.1080/17474086.2021.1875815

6. Kyle RA, Remstein ED, Therneau TM, et al. Clinical course and prognosis of smoldering (asymptomatic) multiple myeloma. $N$ Engl J Med. 2007;356(25):2582-2590. doi:10.1056/ NEJMoa070389

7. Kumar SK, Callander NS, Adekola K, et al. Multiple Myeloma, Version 3.2021, NCCN clinical practice guidelines in oncology. $J$ Natl Compr Canc Netw. 2020;18(12):1685-1717. doi:10.6004/ jncen.2020.0057

8. Chan HS, Chen CI, Reece DE. Current review on high-risk multiple myeloma. Curr Hematol Malig Rep. 2017;12:96-108. doi:10.1007/s11899-017-0368-z

9. Poczta A, Rogalska A, Marczak A. Treatment of multiple myeloma and the role of melphalan in the era of modern therapies-current research and clinical approaches. J Clin Med. 2021;10(9):1841. doi:10.3390/jcm10091841

10. Myeloma - Cancer stat facts; 2021. Available from: https://seer. cancer.gov/statfacts/html/mulmy.html. Accessed August 27, 2021. 
11. Nandakumar B, Binder M, Dispenzieri A, et al. Continued improvement in survival in multiple myeloma (MM) including high-risk patients. J Clin Oncol. 2019;37(Supplement 15):8039. doi:10.1200/JCO.2019.37.15 suppl.8039

12. Braunstein M, Weltz J, Davies F. A new decade: novel immunotherapies on the horizon for relapsed/refractory multiple myeloma. Expert Rev Hematol. 2021;14(4):377-389. doi:10.1080/17474086.2021.1909469

13. Esfahani K, Roudaia L, Buhlaiga N, et al. A review of cancer immunotherapy: from the past, to the present, to the future. Curr Oncol. 2020;27(Suppl 2):S87-s97. doi:10.3747/co.27.5223

14. Waldman AD, Fritz JM, Lenardo MJ. A guide to cancer immunotherapy: from T cell basic science to clinical practice. Nat Rev Immunol. 2020;20(11):651-668. doi:10.1038/s41577-020-0306-5

15. Tan S, Li D, Zhu X. Cancer immunotherapy: pros, cons and beyond. Biomed Pharmacother. 2020;124:109821. doi:10.1016/j. biopha.2020.109821

16. Jiao Y, Yi M, Xu L, et al. CD38: targeted therapy in multiple myeloma and therapeutic potential for solid cancers. Expert Opin Investig Drugs. 2020;29(11):1295-1308. doi:10.1080/13543784.2020.181425

17. Deaglio S, Morra M, Mallone R, et al. Human CD38 (ADP-ribosyl cyclase) is a counter-receptor of CD31, an Ig superfamily member. J Immunol. 1998;160(1):395-402.

18. Aarhus R, Graeff RM, Dickey DM, et al. ADP-ribosyl cyclase and CD38 catalyze the synthesis of a calcium-mobilizing metabolite from NADP. J Biol Chem. 1995;270(51):30327-30333. doi:10.1074/jbc.270.51.30327

19. Laubach JP, Richardson PG. CD38-targeted immunochemotherapy in refractory multiple myeloma: a new horizon. Clin Cancer Res. 2015;21(12):2660-2662. doi:10.1158/1078-0432.ccr-14-3190

20. van de Donk N. Immunomodulatory effects of CD38-targeting antibodies. Immunol Lett. 2018;199:16-22. doi:10.1016/j. imlet.2018.04.005

21. Palumbo A, Chanan-Khan A, Weisel K, et al. Daratumumab, bortezomib, and dexamethasone for multiple myeloma. $N$ Engl $J$ Med. 2016;375(8):754-766. doi:10.1056/NEJMoa1606038

22. Dimopoulos MA, Oriol A, Nahi H, et al. Daratumumab, lenalidomide, and dexamethasone for multiple myeloma. $N$ Engl $J$ Med. 2016;375(14):1319-1331. doi:10.1056/NEJMoa1607751

23. Moreau P, Attal M, Hulin C, et al. Bortezomib, thalidomide, and dexamethasone with or without daratumumab before and after autologous stem-cell transplantation for newly diagnosed multiple myeloma (CASSIOPEIA): a randomised, open-label, Phase 3 study. Lancet. 2019;394:29-38. doi:10.1016/s0140-6736(19)31240-1

24. Durie BGM, Kumar SK, Usmani SZ, et al. Daratumumablenalidomide-dexamethasone vs standard-of-care regimens: efficacy in transplant-ineligible untreated myeloma. Am J Hematol. 2020;95(12):1486-1494. doi:10.1002/ajh.25963

25. Chari A, Suvannasankha A, Fay JW, et al. Daratumumab plus pomalidomide and dexamethasone in relapsed and/or refractory multiple myeloma. Blood. 2017;130(8):974-981. doi:10.1182/ blood-2017-05-785246

26. Dimopoulos M, Quach H, Mateos MV, et al. Carfilzomib, dexamethasone, and daratumumab versus carfilzomib and dexamethasone for patients with relapsed or refractory multiple myeloma (CANDOR): results from a randomised, multicentre, open-label, phase 3 study. Lancet. 2020;396(10245):186-197. doi:10.1016/s0140-6736(20)30734-0

27. Janssen Pharmaceutical Co. U.S. FDA approves new DARZALEX $^{\circledR}$ (daratumumab)-based combination regimen for patients with relapsed/refractory multiple myeloma [press release]. Horsham, PA; 2020. Available from:https://www.prnews wire.com/news-releases/us-fda-approves-new-darzalex-daratumu mab-based-combination-regimen-for-patients-with-relapsedrefrac tory-multiple-myeloma-301116063.html. Accessed June 30, 2021 .
28. Musto P, La Rocca F. Monoclonal antibodies in relapsed/refractory myeloma: updated evidence from clinical trials, real life studies and meta-analyses. Expert Rev Hematol. 2020;13 (4):331-349. doi:10.1080/17474086.2020.1740084

29. Sanchez L, Richter J, Cho HJ, et al. Subcutaneous daratumumab and hyaluronidase-fihj in newly diagnosed or relapsed/refractory multiple myeloma. Ther Adv Hematol. 2021;12:2040620720987075. doi:10.1177/2040620720987075

30. Usmani SZ, Nahi H, Mateos MV, et al. Subcutaneous delivery of daratumumab in relapsed or refractory multiple myeloma. Blood. 2019;134(8):668-677. doi:10.1182/blood.2019000667

31. U.S. Food and Drug Administration. FDA approves daratumumab and hyaluronidase-fihj for multiple myeloma [press release]. Washington, DC; 2020. Available from:https://www.fda.gov/ drugs/resources-information-approved-drugs/fda-approvesdaratumumab-and-hyaluronidase-fihj-multiple-myeloma. Accessed July 29, 2020.

32. Nooka AK, Gleason C, Sargeant MO, et al. Managing infusion reactions to new monoclonal antibodies in multiple myeloma: daratumumab and elotuzumab. J Oncol Pract. 2018;14 (7):414-422. doi:10.1200/jop.18.00143

33. Chapuy CI, Nicholson RT, Aguad MD, et al. Resolving the daratumumab interference with blood compatibility testing. Transfusion. 2015;55(6 Pt 2):1545-1554. doi:10.1111/trf.13069

34. Boyle EM, Petillon MO, Herbaux C, et al. Daratumumab in combination with dexamethasone in resistant or refractory multiple myeloma: primary results of the IFM2014-04 trial. Blood. 2016;128(22):2138. doi:10.1182/blood.V128.22.2138.2138

35. Roussel M, Moreau P, Hebraud B, et al. Bortezomib, thalidomide, and dexamethasone with or without daratumumab for transplantation-eligible patients with newly diagnosed multiple myeloma (CASSIOPEIA): health-related quality of life outcomes of a randomised, open-label, phase 3 trial. Lancet Haematol. 2020;7(12):e874-e883. doi:10.1016/s2352-3026(20)30356-2

36. Chari A, Munder M, Weisel K, et al. Evaluation of cardiac repolarization in the randomized phase 2 study of intermediateor high-risk smoldering multiple myeloma patients treated with daratumumab monotherapy. Adv Ther. 2021;38(2):1328-1341. doi:10.1007/s12325-020-01601-w

37. Leleu X, Beksac M, Chou T, et al. Efficacy and safety of weekly carfilzomib (70 $\mathrm{mg} / \mathrm{m}(2))$, dexamethasone, and daratumumab (KdD70) is comparable to twice-weekly KdD56 while being a more convenient dosing option: a cross-study comparison of the CANDOR and EQUULEUS studies. Leuk Lymphoma. 2021;62(2):358-367. doi:10.1080/10428194.2020.1832672

38. Usmani SZ, Quach H, Mateos MV, et al. Carfilzomib, dexamethasone, and daratumumab versus carfilzomib and dexamethasone for the treatment of patients with relapsed or refractory multiple myeloma (RRMM): primary analysis results from the randomized, open-label, phase 3 study CANDOR (NCT03158688). Blood. 2019;134:LBA-6. doi:10.1182/blood-2019-132629

39. Weisel K, Spencer A, Lentzsch S, et al. Daratumumab, bortezomib, and dexamethasone in relapsed or refractory multiple myeloma: subgroup analysis of CASTOR based on cytogenetic risk. $J$ Hematol Oncol. 2020;13(1):115. doi:10.1186/s13045-020-00948-5

40. Rajkumar SV, Voorhees PM, Goldschmidt H, et al. Randomized, open-label, phase 3 study of subcutaneous daratumumab (DARA SC) versus active monitoring in patients (pts) with high-risk smoldering multiple myeloma (SMM): AQUILA. J Clin Oncol. 2018;36(15):2. doi:10.1200/JCO.2018.36.15_suppl.TPS8062

41. Dimopoulos MA, San-Miguel J, Belch A, et al. Daratumumab plus lenalidomide and dexamethasone versus lenalidomide and dexamethasone in relapsed or refractory multiple myeloma: updated analysis of POLLUX. Haematologica. 2018. doi:10.3324/haematol.2018.194282 
42. Plesner T, Dimopoulos MA, Oriol A, et al. Health-related quality of life in patients with relapsed or refractory multiple myeloma: treatment with daratumumab, lenalidomide, and dexamethasone in the phase 3 POLLUX trial. Br J Haematol. 2021;194:132-139. doi:10.1111/bjh.17435

43. Sonneveld P, Terpos E, Dimopoulos MA, et al. Pomalidomide and dexamethasone (pom-dex) with or without daratumumab (DARA) in patients (pts) with relapsed or refractory multiple myeloma (RRMM): a multicenter, randomized, phase 3 study (APOLLO). J Clin Oncol. 2018;36(15):1. doi:10.1200/ JCO.2018.36.15_suppl.TPS8059

44. Perrot A, Facon T, Plesner T, et al. Health-related quality of life in transplant-ineligible patients with newly diagnosed multiple myeloma: findings from the phase III MAIA trial. J Clin Oncol. 2021;39(3):227-237. doi:10.1200/jco.20.01370

45. Facon T, Kumar S, Plesner T, et al. Daratumumab plus lenalidomide and dexamethasone for untreated myeloma. $N$ Engl J Med. 2019;380(22):2104-2115. doi:10.1056/NEJMoa1817249

46. Usmani SZ, Mateos MV, Hungria V, et al. Greater treatment satisfaction in patients receiving daratumumab subcutaneous vs. intravenous for relapsed or refractory multiple myeloma: COLUMBA clinical trial results. J Cancer Res Clin Oncol. 2021;147:619-631. doi:10.1007/s00432-020-03365-w

47. Iida S, Ishikawa T, Min CK, et al. Subcutaneous daratumumab in Asian patients with heavily pretreated multiple myeloma: subgroup analyses of the noninferiority, phase 3 COLUMBA study. Ann Hematol. 2021;100(4):1065-1077. doi:10.1007/s00277-021-04405-2

48. Mateos MV, Usmani SZ. Subcutaneous versus intravenous daratumumab in multiple myeloma - Authors' reply. Lancet Haematol. 2020;7(8):e559. doi:10.1016/s2352-3026(20)30188-5

49. Moreno L, Perez C, Zabaleta A, et al. The mechanism of action of the anti-CD38 monoclonal antibody isatuximab in multiple myeloma. Clin Cancer Res. 2019;25(10):3176-3187. doi:10.1158/1078-0432.Ccr-18-1597

50. Dhillon S. Isatuximab: first approval. Drugs. 2020;80 (9):905-912. doi:10.1007/s40265-020-01311-1

51. Attal M, Richardson PG, Rajkumar SV, et al. Isatuximab plus pomalidomide and low-dose dexamethasone versus pomalidomide and low-dose dexamethasone in patients with relapsed and refractory multiple myeloma (ICARIA-MM): a randomised, multicentre, open-label, phase 3 study. Lancet. 2019;394 (10214):2096-2107. doi:10.1016/s0140-6736(19)32556-5

52. Richter J, Sanchez L, Thibaud S. Therapeutic potential of isatuximab in the treatment of multiple myeloma: evidence to date. Semin Oncol. 2020;47(2-3):155-164. doi:10.1053/j. seminoncol.2020.04.004

53. U.S. Food and Drug Administration. FDA approves isatuximab-irfc for multiple myeloma [press release]. Washington, DC; 2021. Available from:https://www.fda.gov/ drugs/resources-information-approved-drugs/fda-approvesisatuximab-irfc-multiple-myeloma. Accessed April 15, 2021.

54. Moreau P, Dimopoulos MA, Yong $\mathrm{K}$, et al. Isatuximab plus carfilzomib/dexamethasone versus carfilzomib/dexamethasone in patients with relapsed/refractory multiple myeloma: IKEMA Phase III study design. Future Oncol. 2020;16(2):4347-4358. doi:10.2217/fon-2019-0431

55. Martin T, Mikhael J, Hajek R, et al. Depth of response and response kinetics of isatuximab plus carfilzomib and dexamethasone in relapsed multiple myeloma: ikema interim analysis. Blood. 2020;136(Supplement 1):7-8. doi:10.1182/blood-2020137681

56. Bringhen S, Pour L, Vorobyev V, et al. Isatuximab plus pomalidomide and dexamethasone in patients with relapsed/refractory multiple myeloma according to prior lines of treatment and refractory status: ICARIA-MM subgroup analysis. Leuk Res. 2021;104:106576. doi:10.1016/j.leukres.2021.106576
57. Richardson PG, Attal M, Campana F, et al. Isatuximab plus pomalidomide/dexamethasone versus pomalidomide/dexamethasone in relapsed/refractory multiple myeloma: ICARIA Phase III study design. Future Oncol. 2018;14(11):1035-1047. doi:10.2217/fon-2017-0616

58. Richardson PG, Attal M, San Miguel J, et al. A phase III, randomized, open-label study of isatuximab (SAR650984) plus pomalidomide (Pom) and dexamethasone (Dex) versus Pom and Dex in relapsed/refractory multiple myeloma. J Clin Oncol. 2017;35 Supplement 15:TPS8057. doi:10.1200/ JCO.2017.35.15_suppl.TPS8057

59. Harrison SJ, Perrot A, Alegre A, et al. Subgroup analysis of ICARIA-MM study in relapsed/refractory multiple myeloma patients with high-risk cytogenetics. $\mathrm{Br} J$ Haematol. 2021;184:120-131. doi:10.1111/bjh.17499

60. Chari A, Richter JR, Shah N, et al. Phase I-b study of isatuximab + carfilzomib in relapsed and refractory multiple myeloma (RRMM). J Clin Oncol. 2018;36(Supplement 15):8014. doi:10.1200/JCO.2018.36.15_suppl

61. Thai HT, Gaudel-Dedieu $\bar{N}$, Cerou M, et al. Model based approach to evaluate isatuximab monthly dosing regimen in relapsed/refractory multiple myeloma patients. Blood. 2020;136 (Supplement 1):44. doi:10.1182/blood-2020-139358

62. Manasanch EE, Jagannath S, Lee HC, et al. A multicenter phase II single arm trial of isatuximab in patients with high risk smoldering multiple myeloma (HRSMM). Blood. 2019;134 (Supplement 1):3116. doi:10.1182/blood-2019-123205

63. Martin III TG, Mannis GN, Chari A, et al. Phase Ib study of isatuximab and carfilzomib in relapse and refractory multiple myeloma. Blood. 2016;128(22):2111. doi:10.1182/blood. V128.22.2111.2111

64. Orlowski RZ, Goldschmidt H, Cavo M, et al. Phase III (IMROZ) study design: isatuximab plus bortezomib (V), lenalidomide (R), and dexamethasone (d) vs VRd in transplant-ineligible patients (pts) with newly diagnosed multiple myeloma (NDMM). J Clin Oncol. 2018;36 Supplement 15:TPS8055. doi:10.1200/ JCO.2018.36.15_suppl.TPS805

65. Martin T, Richter J, Vij R, et al. A dose finding phase II trial of isatuximab (SAR650984, anti-CD38 $\mathrm{mAb}$ ) as a single agent in relapsed/refractory multiple myeloma. Blood. 2015;126(23):509. doi:10.1182/blood.V126.23.509.509

66. Martin T, Baz R, Benson DM, et al. A Phase 1b study of isatuximab plus lenalidomide and dexamethasone for relapsed/ refractory multiple myeloma. Blood. 2017;129(25):3294-3303. doi:10.1182/blood-2016-09-740787

67. Mikhael J, Richardson PG, Usmani SZ, et al. A phase Ib study of isatuximab in combination with pomalidomide (Pom) and dexamethasone (Dex) in relapsed/refractory multiple myeloma (RRMM). J Clin Oncol. 2017;35(Supplement 15):8038. doi:10.1200/JCO.2018.36.15_suppl.8038

68. Mikhael J, Richardson PG, Usmani SZ, et al. Final results of a phase Ib study of isatuximab (ISA) plus pomalidomide (Pom) and dexamethasone (dex) in relapsed/refractory multiple myeloma (RRMM). J Clin Oncol. 2018;36:8038. doi:10.1200/ JCO.2018.36.15_suppl.8038

69. Mikhael J, Richardson P, Usmani SZ, et al. A phase 1b study of isatuximab plus pomalidomide/dexamethasone in relapsed/refractory multiple myeloma. Blood. 2019;134(2):123-133. doi:10.1182/blood-2019-02-895193

70. Usmani SZ, Karanes C, Bensinger WI, et al. Final results of a phase $1 \mathrm{~b}$ study of isatuximab short-duration fixed-volume infusion combination therapy for relapsed/refractory multiple myeloma. Leukemia. 2021. doi:10.1038/s41375-021-01262-w

71. Grosicki S, Bednarczyk M, Barchnicka A, et al. Elotuzumab in the treatment of relapsed and refractory multiple myeloma. Future Oncol. 2021;17(13):1581-1591. doi:10.2217/fon-2020-1088 
72. Gavriatopoulou M, Terpos E, Kastritis E, et al. Efficacy and safety of elotuzumab for the treatment of multiple myeloma. Expert Opin Drug Saf. 2017;16(2):237-245. doi:10.1080/ 14740338.2017.1279603

73. Collins SM, Bakan CE, Swartzel GD, et al. Elotuzumab directly enhances NK cell cytotoxicity against myeloma via CS1 ligation: evidence for augmented NK cell function complementing ADCC. Cancer Immunol Immunother. 2013;62(12):1841-1849. doi:10.1007/s00262-013-1493-8

74. Hsi ED, Steinle R, Balasa B, et al. CS1, a potential new therapeutic antibody target for the treatment of multiple myeloma. Clin Cancer Res. 2008;14(9):2775-2784. doi:10.1158/1078-0432. ccr-07-4246

75. Markham A. Elotuzumab: first global approval. Drugs. 2016;76 (3):397-403. doi:10.1007/s40265-016-0540-0

76. Zonder JA, Mohrbacher AF, Singhal S, et al. A phase 1, multicenter, open-label, dose escalation study of elotuzumab in patients with advanced multiple myeloma. Blood. 2012;120(3):552-559. doi:10.1182/blood-2011-06-360552

77. Lonial S, Dimopoulos M, Palumbo A, et al. Elotuzumab therapy for relapsed or refractory multiple myeloma. $N$ Engl $J$ Med 2015;373(7):621-631. doi:10.1056/NEJMoa1505654

78. Dimopoulos MA, Lonial S, Betts KA, et al. Elotuzumab plus lenalidomide and dexamethasone in relapsed/refractory multiple myeloma: extended 4-year follow-up and analysis of relative progression-free survival from the randomized ELOQUENT-2 trial. Cancer. 2018;124(20):4032-4043. doi:10.1002/cncr.31680

79. Dimopoulos MA, Dytfeld D, Grosicki S, et al. Elotuzumab plus pomalidomide and dexamethasone for multiple myeloma. $N \mathrm{Engl}$ J Med. 2018;379(19):1811-1822. doi:10.1056/NEJMoa1805762

80. Trudel S, Moreau P, Touzeau C. Update on elotuzumab for the treatment of relapsed/refractory multiple myeloma: patients' selection and perspective. Onco Targets Ther 2019;12:5813-5822. doi:10.2147/ott.S174640

81. Usmani SZ, Hoering A, Ailawadhi S, et al. Bortezomib, lenalidomide, and dexamethasone with or without elotuzumab in patients with untreated, high-risk multiple myeloma (SWOG-1211): primary analysis of a randomised, phase 2 trial. Lancet Haematol. 2021;8(1):e45-e54. doi:10.1016/s23523026(20)30354-9

82. Jakubowiak AJ, Benson DM, Bensinger W, et al. Phase I trial of anti-CS1 monoclonal antibody elotuzumab in combination with bortezomib in the treatment of relapsed/refractory multiple myeloma. J Clin Oncol. 2012;30(16):1960-1965. doi:10.1200/ jco.2011.37.7069

83. Silvennoinen RH, Nahi H, Anttila P, et al. Carfilzomib, elotuzumab and dexamethasone for relapsed or refractory myeloma patients. Blood. 2020;136(Supplement 1):20. doi:10.1182/blood2020-138447

84. Yee AJ, Laubach J, Campagnaro EL, et al. A phase II study of elotuzumab in combination with pomalidomide, bortezomib, and dexamethasone in relapsed and refractory multiple myeloma. $J$ Clin Oncol. 2018;36(Supplement 15):8012. doi:10.1200/ JCO.2018.36.15_suppl.8012

85. Berenson J, Manges R, Badarinath S, et al. A phase 2 safety study of accelerated elotuzumab infusion, over less than $1 \mathrm{~h}$, in combination with lenalidomide and dexamethasone, in patients with multiple myeloma. Am J Hematol. 2017;92(5):460-466. doi:10.1002/ajh.24687

86. Jakubowiak A, Offidani M, Pegourie B, et al. Randomized phase 2 study: elotuzumab plus bortezomib/dexamethasone vs bortezo$\mathrm{mib} /$ dexamethasone for relapsed/refractory MM. Blood. 2016;127 (23):2833-2840. doi:10.1182/blood-2016-01-694604

87. Jagannath S, Laubach J, Wong E, et al. Elotuzumab monotherapy in patients with smouldering multiple myeloma: a phase 2 study. Br J Haematol. 2018;182:495-503. doi:10.1111/bjh.15384
88. Passey C, Darbenzio R, Jou YM, et al. Effects of elotuzumab on QT interval and cardiac safety in patients with multiple myeloma. Cancer Chemother Pharmacol. 2016;78(6):1237-1244. doi:10.1007/s00280-016-3182-8

89. Salwender H, Bertsch U, Weisel K, et al. Rationale and design of the German-speaking myeloma multicenter group (GMMG) trial HD6: a randomized phase III trial on the effect of elotuzumab in VRD induction/consolidation and lenalidomide maintenance in patients with newly diagnosed myeloma. BMC Cancer. 2019;19 (1):504. doi:10.1186/s12885-019-5600-x

90. Usmani SZ, Ailawadhi S, Sexton R, et al. Primary analysis of the randomized phase II trial of bortezomib, lenalidomide, dexamthasone with/without elotuzumab for newly diagnosed, high-risk multiple myeloma (SWOG-1211). J Clin Oncol. 2020;38 Supplement 15:8507. doi:10.1200/JCO.2020.38.15_suppl.8507

91. Passey C, Mora J, Dodge R, et al. An integrated assessment of the effects of immunogenicity on the pharmacokinetics, safety, and efficacy of elotuzumab. Aaps j. 2017;19(2):557-567. doi:10.1208/ s12248-016-0033-9

92. Taniwaki M, Yoshida M, Matsumoto Y, et al. Elotuzumab for the treatment of relapsed or refractory multiple myeloma, with special reference to its modes of action and SLAMF7 signaling. Mediterr J Hematol Infect Dis. 2018;10(1):e2018014. doi:10.4084/mjhid.2018.014

93. Dimopoulos MA, Lonial S, White D, et al. Elotuzumab plus lenalidomide/dexamethasone for relapsed or refractory multiple myeloma: ELOQUENT-2 follow-up and post-hoc analyses on progression-free survival and tumour growth. Br J Haematol. 2017;178(6):896-905. doi:10.1111/bjh.14787

94. Dimopoulos MA, Lonial S, White D, et al. Elotuzumab, lenalidomide, and dexamethasone in RRMM: final overall survival results from the phase 3 randomized ELOQUENT-2 study. Blood Cancer J. 2020;10(9):91. doi:10.1038/s41408-020-00357-4

95. Richardson PG, Jagannath S, Moreau P, et al. Elotuzumab in combination with lenalidomide and dexamethasone in patients with relapsed multiple myeloma: final phase 2 results from the randomised, open-label, phase 1b-2 dose-escalation study. Lancet Haematol. 2015;2(12):e516-527. doi:10.1016/s2352-3026(15)00197-0

96. Lonial S, Richardson PG, Reece DE, et al. CheckMate 602: an open-label, randomized, phase 3 trial of combinations of nivolumab, elotuzumab, pomalidomide and dexamethasone in relapsed/ refractory multiple myeloma. J Clin Oncol. 2017;35(15):8052. doi:10.1200/JCO.2017.35.15_suppl.TPS8052

97. Yu J, Song Y, Tian W. How to select IgG subclasses in developing anti-tumor therapeutic antibodies. J Hematol Oncol. 2020;13 (1):45. doi:10.1186/s13045-020-00876-4

98. Pereira NA, Chan KF, Lin PC, et al. The "less-is-more" in therapeutic antibodies: afucosylated anti-cancer antibodies with enhanced antibody-dependent cellular cytotoxicity. mAbs. 2018;10(5):693-711. doi:10.1080/19420862.2018.1466767

99. Pan J, Sun Y, Zhang N, et al. Characteristics of BAFF and APRIL factor expression in multiple myeloma and clinical significance. Oncol Lett. 2017;14(3):2657-2662. doi:10.3892/ol.2017.6528

100. Raje NS, Moreau P, Terpos E, et al. Phase 2 study of tabalumab, a human anti-B-cell activating factor antibody, with bortezomib and dexamethasone in patients with previously treated multiple myeloma. Br J Haematol. 2017;176(5):783-795. doi:10.1111/ bjh. 14483

101. Rossi J-F, Moreaux J, Hose D, et al. Atacicept in relapsed/refractory multiple myeloma or active Waldenström's macroglobulinemia: a phase I study. Br J Cancer. 2009;101(7):1051-1058. doi:10.1038/sj.bjc.6605241

102. Laabi Y, Gras M-P, Brouet J-C, et al. The BCMA gene, preferentially expressed during B lymphoid maturation, is bidirectionally transcribed. Nucleic Acids Res. 1994;22(7):1147-1154. doi:10.1093/nar/22.7.1147 
103. Kozlow EJ, Wilson GL, Fox CH, et al. Subtractive cDNA cloning of a novel member of the Ig gene superfamily expressed at high levels in activated B lymphocytes. Blood. 1993;81(2):454-461. doi:10.1182/blood.V81.2.454.454

104. Zhou LJ, Schwarting R, Smith HM, et al. A novel cell-surface molecule expressed by human interdigitating reticulum cells, Langerhans cells, and activated lymphocytes is a new member of the Ig superfamily. J Immunol. 1992;149(2):735-742.

105. Laabi Y, Gras MP, Carbonnel F, et al. A new gene, BCM, on chromosome 16 is fused to the interleukin 2 gene by a $\mathrm{t}(4 ; 16)(\mathrm{q} 26$; p13) translocation in a malignant $\mathrm{T}$ cell lymphoma. EMBO $\mathrm{J}$. 1992;11(11):3897-3904. doi:10.1002/j.1460-2075.1992.tb05482.x

106. Cho SF, Anderson KC, Tai YT. Targeting B cell maturation antigen (BCMA) in multiple myeloma: potential uses of BCMA-based immunotherapy. Front Immunol. 2018;9:1821. doi:10.3389/fimmu.2018.01821

107. Cho SF, Lin L, Xing L, et al. BCMA-targeting therapy: driving a new era of immunotherapy in multiple myeloma. Cancers. 2020;12(6):1473. doi:10.3390/cancers12061473

108. Fang Y, Hou J. Immunotherapeutic strategies targeting B cell maturation antigen in multiple myeloma. Mil Med Res. 2021;8 (1):9. doi:10.1186/s40779-021-00302-x

109. Shah N, Chari A, Scott E, et al. B-cell maturation antigen (BCMA) in multiple myeloma: rationale for targeting and current therapeutic approaches. Leukemia. 2020;34(4):985-1005. doi:10.1038/s41375-020-0734-z

110. Sanchez E, Tanenbaum EJ, Patil S, et al. The clinical significance of B-cell maturation antigen as a therapeutic target and biomarker. Expert Rev Mol Diagn. 2018;18(4):319-329. doi:10.1080/ 14737159.2018.1448269

111. Laurent SA, Hoffmann FS, Kuhn PH, et al. Gamma-secretase directly sheds the survival receptor BCMA from plasma cells. Nat Commun. 2015;6:7333. doi:10.1038/ncomms 8333

112. Sanchez E, Li M, Kitto A, et al. Serum B-cell maturation antigen is elevated in multiple myeloma and correlates with disease status and survival. Br J Haematol. 2012;158(6):727-738. doi:10.1111/ j.1365-2141.2012.09241.x

113. Pont MJ, Hill T, Cole GO, et al. Gamma-secretase inhibition increases efficacy of BCMA-specific chimeric antigen receptor T cells in multiple myeloma. Blood. 2019;134(19):1585-1597. doi:10.1182/blood.2019000050

114. Sanchez E, Gillespie A, Tang G, et al. Soluble B-cell maturation antigen mediates tumor-induced immune deficiency in multiple myeloma. Clin Cancer Res. 2016;22(13):3383-3397. doi:10.1158/1078-0432.Ccr-15-2224

115. Lassiter G, Bergeron C, Guedry R, et al. Belantamab mafodotin to treat multiple myeloma: a comprehensive review of disease, drug efficacy and side effects. Curr Oncol. 2021;28(1):640-660. doi:10.3390/curroncol28010063

116. Tai YT, Anderson KC. Targeting B-cell maturation antigen in multiple myeloma. Immunotherapy. 2015;7(11):1187-1199. doi:10.2217/imt.15.77

117. Tai YT, Mayes PA, Acharya C, et al. Novel afucosylated anti-B cell maturation antigen-monomethyl auristatin $F$ antibody-drug conjugate (GSK2857916) induces potent and selective anti-multiple myeloma activity. Blood. 2014;123 (20):3128-3138. doi:10.1182/blood-2013-10-535088

118. U.S. Food and Drug Administration. FDA granted accelerated approval to belantamab mafodotin-blmf for multiple myeloma [press release]. Washington, DC; 2020. Available from:https://www. fda.gov/drugs/resources-information-approved-drugs/fda-granted -accelerated-approval-belantamab-mafodotin-blmf-multiple-mye loma. Accessed May 5, 2021.
119. Lonial S, Lee HC, Badros A, et al. Belantamab mafodotin for relapsed or refractory multiple myeloma (DREAMM-2): a two-arm, randomised, open-label, phase 2 study. Lancet Oncol. 2019;21(2):207-221. doi:10.1016/s1470-2045(19) 30788-0

120. Farooq AV, Degli Esposti S, Popat R, et al. Corneal epithelial findings in patients with multiple myeloma treated with antibody-drug conjugate belantamab mafodotin in the pivotal, randomized, DREAMM-2 study. Ophthalmol Ther. 2020;9:889-911. doi:10.1007/s40123-020-00280-8

121. Eaton JS, Miller PE, Mannis MJ, et al. Ocular adverse events associated with antibody-drug conjugates in human clinical trials. $\mathrm{J} \mathrm{Ocul}$ Pharmacol Ther. 2015;31(10):589-604. doi:10.1089/jop.2015.0064

122. Lee HC, Raje NS, Landgren O, et al. Letter: phase 1 study of the anti-BCMA antibody-drug conjugate AMG 224 in patients with relapsed/refractory multiple myeloma. Leukemia. 2020;35:255-258. doi:10.1038/s41375-020-0834-9

123. Joubert N, Beck A, Dumontet C, et al. Antibody-drug conjugates: the last decade. Pharmaceuticals. 2020;13(9):245. doi:10.3390/ ph13090245

124. Pahl A, Lutz C, Hechler T. Amanitins and their development as a payload for antibody-drug conjugates. Drug Discov Today Technol. 2018;30:85-89. doi:10.1016/j.ddtec.2018.08.005

125. Spycher PR, Frei JC, Wehrmuller JE, et al. Overcoming limitations of current antibody-drug conjugates (ADCs) by a novel linker technology. Cancer Res. 2019;79(13):LB-106. doi:10.1158/1538-7445.Am2019-1b-106

126. Figueroa-Vazquez V, Ko J, Breunig C, et al. HDP-101, an anti-BCMA antibody-drug conjugate, safely delivers amanitin to induce cell death in proliferating and resting multiple myeloma cells. Mol Cancer Ther. 2021;20(2):367-378. doi:10.1158/15357163.Mct-20-0287

127. Heidelberg Pharma AG FDA allows Heidelberg Pharma to start a phase I/IIa clinical trial with ATAC candidate HDP-101 [press release]. Ladenburg, Germany; 2021. Available from: https://pipelinereview.com/index.php/2021020477353/ Antibodies/FDA-Allows-Heidelberg-Pharma-to-Start-A-PhaseI/IIa-Clinical-Trial-with-ATAC-Candidate-HDP-101.html. Accessed: June 25, 2021.

128. Trudel S, Lendvai N, Popat R, et al. Deep and durable responses in patients (pts) with relapsed/refractory multiple myeloma (MM) treated with monotherapy GSK2857916, an antibody drug conjugate against B-cell maturation antigen (BCMA): preliminary results from part 2 of study BMA117159. Blood. 2017;130:741. doi:10.1182/blood.V130.Suppl_1.741.741

129. Popat R, Suvannasankha A, Kapetanakis V, et al. DREAMM-2: assessing efficacy via indirect comparison of single-agent belantamab mafodotin versus selinexor plus dexamethasone combination in anti-CD38 exposed relapsed/refractory multiple myeloma (RRMM). J Clin Oncol. 2020;38 Supplement 15:e20527. doi:10.1200/JCO.2020.38.15_suppl.e20527

130. Richardson PG, Lee HC, Abdallah AO, et al. Single-agent belantamab mafodotin for relapsed/refractory multiple myeloma: analysis of the lyophilised presentation cohort from the pivotal DREAMM-2 study. Blood Cancer J. 2020;10(10):106. doi:10.1038/s41408-020-00369-0

131. Weisel K, Hopkins TG, Fecteau D, et al. DREAMM-3: a phase 3 , open-label, randomized study to evaluate the efficacy and safety of belantamab mafodotin (GSK2857916) monotherapy compared with pomalidomide plus low-dose dexamethasone (pom/dex) in participants with relapsed/refractory multiple myeloma (RRMM). Blood. 2019;134 Supplement 1:1900. doi:10.1182/blood-2019-129893 
132. Trudel S, Nooka A, Fecteau D, et al. DREAMM 4: a phase I/II single-arm open-label study to explore safety and clinical activity of belantamab mafodotin (GSK2857916) administered in combination with pembrolizumab in patients with relapsed/refractory multiple myeloma (RRMM). Ann Oncol. 2019;30 Supplement 5: V447. doi:10.1093/annonc/mdz251.039

133. Nooka AK, Stockerl-Goldstein K, Quach H, et al. DREAMM-6: safety and tolerability of belantamab mafodotin in combination with bortezomib/dexamethasone in relapsed/refractory multiple myeloma (RRMM). J Clin Oncol. 2020;38 Supplement 15:8502. doi:10.1200/JCO.2020.38.15_suppl.8502

134. Popat R, Nooka A, Stockerl-Goldstein K, et al. DREAMM-6: safety, tolerability and clinical activity of belantamab mafodotin (belamaf) in combination with bortezomib/dexamethasone (bordex) in relapsed/refractory multiple myeloma. Blood. 2020;136 (Supplement 1):19-20. doi:10.1182/blood-2020-139332

135. Rifkin RM, Boyd K, Grosicki S, et al. DREAMM-7: a phase III study of the efficacy and safety of belantamab mafodotin (belamaf) with bortezomib, and dexamethasone $(\mathrm{B}-\mathrm{Vd})$ in patients with relapsed/refractory multiple myeloma (RRMM). Blood. 2020;136(Supplement 1):53-54. doi:10.1182/blood-2020-139181

136. Trudel S, Davis R, Lewis NM, et al. DREAMM-8: a phase III study of the efficacy and safety of belantamab mafodotin with pomalidomide and dexamethasone (B-Pd) vs pomalidomide plus bortezomib and dexamethasone (PVd) in patients with relapsed/ refractory multiple myeloma (RRMM). Blood. 2020;136 (Supplement 1):4. doi:10.1182/blood-2020-139785

137. Usmani SZ, Terpos E, Janowski W, et al. DREAMM-9: phase III study of belantamab mafodotin plus VRd versus VRd alone in transplant-ineligible newly diagnosed multiple myeloma (TI NDMM). J Clinical Oncol. 2020;38(15):TPS8556. doi:10.1200/ JCO.2020.38.15_suppl.TPS8556

138. Nisonoff A, Rivers MM. Recombination of a mixture of univalent antibody fragments of different specificity. Arch Biochem Biophys. 1961;93:460-462. doi:10.1016/0003-9861(61)90296-x

139. Huang S, van Duijnhoven SMJ, Sijts A, et al. Bispecific antibodies targeting dual tumor-associated antigens in cancer therapy. $J$ Cancer Res Clin Oncol. 2020;146(12):3111-3122. doi:10.1007/ s00432-020-03404-6

140. Rader C. Bispecific antibodies in cancer immunotherapy. Curr Opin Biotechnol. 2020;65:9-16. doi:10.1016/j.copbio.2019.11.020

141. Wang Q, Chen Y, Park J, et al. Design and production of bispecific antibodies. Antibodies. 2019;8(3):43. doi:10.3390/ antib8030043

142. Spicer BA, Conroy PJ, Law RHP, et al. Perforin-A key (shaped) weapon in the immunological arsenal. Semin Cell Dev Biol. 2017;72:117-123. doi:10.1016/j.semcdb.2017.07.033

143. Voskoboinik I, Whisstock JC, Trapani JA. Perforin and granzymes: function, dysfunction and human pathology. Nat Rev Immunol. 2015;15(6):388-400. doi:10.1038/nri3839

144. Baeuerle PA, Reinhardt C. Bispecific T-cell engaging antibodies for cancer therapy. Cancer Res. 2009;69(12):4941-4944. doi:10.1158/0008-5472.Can-09-0547

145. Mandikian D, Takahashi N, Lo AA, et al. Relative target affinities of T-cell-dependent bispecific antibodies determine biodistribution in a solid tumor mouse model. Mol Cancer Ther. 2018;17 (4):776-785. doi:10.1158/1535-7163.Mct-17-0657

146. Mazor Y, Sachsenmeier KF, Yang C, et al. Enhanced tumor-targeting selectivity by modulating bispecific antibody binding affinity and format valence. Sci Rep. 2017;7:40098. doi:10.1038/srep40098

147. Velders MP, van Rhijn CM, Oskam E, et al. The impact of antigen density and antibody affinity on antibody-dependent cellular cytotoxicity: relevance for immunotherapy of carcinomas. $\mathrm{Br}$ J Cancer. 1998;78(4):478-483. doi:10.1038/bjc.1998.518
148. Jen EY, Xu Q, Schetter A, et al. FDA approval: blinatumomab for patients with B-cell precursor acute lymphoblastic leukemia in morphologic remission with minimal residual disease. Clin Cancer Res. 2019;25(2):473-477. doi:10.1158/1078-0432.Ccr18-2337

149. Sanford M. Blinatumomab: first global approval. Drugs. 2015;75 (3):321-327. doi:10.1007/s40265-015-0356-3

150. Haas KM, Tedder TF. Role of the CD19 and CD21/35 receptor complex in innate immunity, host defense and autoimmunity. $A d v$ Exp Med Biol. 2005;560:125-139. doi:10.1007/0-387-24180916

151. Wang K, Wei G, Liu D. CD19: a biomarker for B cell development, lymphoma diagnosis and therapy. Exp Hematol Oncol. 2012;1(1):36. doi:10.1186/2162-3619-1-36

152. Nerreter T, Letschert S, Gotz R, et al. Super-resolution microscopy reveals ultra-low CD19 expression on myeloma cells that triggers elimination by CD19 CAR-T. Nat Commun. 2019;10 (1):3137. doi:10.1038/s41467-019-10948-w

153. Abramson HN. B-cell maturation antigen (BCMA) as a target for new drug development in relapsed and/or refractory multiple myeloma. Int J Mol Sci. 2020;21(15):5192. doi:10.3390/ ijms21155192

154. Caraccio C, Krishna S, Phillips DJ, et al. Bispecific antibodies for multiple myeloma: a review of targets, drugs, clinical trials, and future directions. Front Immunol. 2020;11:501. doi:10.3389/ fimmu.2020.00501

155. Martino M, Paviglianiti A. An update on B-cell maturation antigen-targeted therapies in multiple myeloma. Expert Opin Biol Ther. 2021;1-10. doi:10.1080/14712598.2021.1872540

156. Sanchez L, Dardac A, Madduri D, et al. B-cell maturation antigen (BCMA) in multiple myeloma: the new frontier of targeted therapies. Ther Adv Hematol. 2021;12:2040620721989585. doi:10.1177/2040620721989585

157. Topp MS, Duell J, Zugmaier G, et al. Anti-B-cell maturation antigen BiTE molecule AMG 420 induces responses in multiple myeloma. J Clin Oncol. 2020;38(8):775-783. doi:10.1200/jco.19.02657

158. Cho SF, Lin L, Xing L, et al. The immunomodulatory drugs lenalidomide and pomalidomide enhance the potency of AMG 701 in multiple myeloma preclinical models. Blood Advances. 2020;4(17):4195-4207. doi:10.1182/bloodadvances.2020002524

159. Harrison SJ, Minnema MC, Lee $\mathrm{HC}$, et al. A phase 1 first in human (FIH) study of AMG 701, an anti-B-cell maturation antigen (BCMA) half-life extended (HLE) BiTE (R) (bispecific T-cell engager) molecule, in relapsed/refractory (RR) multiple myeloma (MM). Blood. 2020;136 Supplement 1:28-29. doi:10.1182/blood-2020-134063

160. Amgen Inc. Amgen reports fourth quarter and full year 2020 financial results [press release]. Thousand Oaks, CA; 2021. Available from:https://investors.amgen.com/news-releases/newsrelease-details/amgen-reports-fourth-quarter-and-full-year-2020financial/. Accessed May 21, 2021.

161. Lancman G, Richter J, Chari A. Bispecifics, trispecifics, and other novel immune treatments in myeloma. Hematology Am Soc Hematol Educ Program. 2020;2020(1):264-271. doi:10.1182/ hematology.2020000110

162. Cooper D, Madduri D, Lentzsch S, et al. Safety and preliminary clinical activity of REGN5458, an anti-BCMA x anti-CD3 bispecific antibody, in patients with relapsed/refractory multiple myeloma. Blood. 2019;134:3176. doi:10.1182/blood-2019-126818

163. DiLillo DJ, Olson K, Mohrs K, et al. A BCMAxCD3 bispecific T cell-engaging antibody demonstrates robust antitumor efficacy similar to that of anti-BCMA CAR T cells. Blood Advances. 2021;5(5):1291-1304. doi:10.1182/bloodadvances.2020002736

164. Girgis S, Shetty S, Jiao T, et al. Exploratory pharmacokinetic/ pharmacodynamic and tolerability study of BCMAxCD3 in cynomolgus monkeys. Blood. 2016;128:5668. doi:10.1182/blood. V128.22.5668.5668 
165. Pillarisetti K, Powers G, Luistro L, et al. Teclistamab is an active $\mathrm{T}$ cell-redirecting bispecific antibody against B-cell maturation antigen for multiple myeloma. Blood Advances. 2020;4 (18):4538-4549. doi:10.1182/bloodadvances.2020002393

166. Garfall AL, Usmani SZ, Mateos MV, et al. Updated phase 1 results of teclistamab, a B-cell maturation antigen (BCMA) $\mathrm{x}$ CD3 bispecific antibody, in relapsed and/or refractory multiple myeloma (RRMM). Blood. 2020;136:4. doi:10.1182/blood-2020138831

167. Usmani SZ, Mateos MV, Nahi H, et al. Phase I study of teclistamab, a humanized B-cell maturation antigen (BCMA) x CD3 bispecific antibody, in relapsed/refractory multiple myeloma $(\mathrm{R} /$ R MM). J Clin Oncol. 2020;38(15Supplement):100. doi:10.1200/ JCO.2020.38.15_suppl.100

168. Krishnan AY, Garfall AL, Mateos MV, et al. Updated phase 1 results of teclistamab, a B-cell maturation antigen $(\mathrm{BCMA}) \times$ CD3 bispecific antibody, in relapsed/refractory multiple myeloma (MM). J Clin Oncol. 2021;39(15Supplement):8007. doi:10.1200/ JCO.2021.39.15_suppl.8007

169. Suzuki S, Annaka H, Konno S, et al. Engineering the hinge region of human IgG1 Fc-fused bispecific antibodies to improve fragmentation resistance. Sci Rep. 2018;8(1):17253. doi:10.1038/ s41598-018-35489-y

170. Lesokhin AM, Raje N, Gasparetto CJ, et al. A phase I, open-label study to evaluate the safety, pharmacokinetic, pharmacodynamic, and clinical activity of PF-06863135, a B-cell maturation antigen/ CD3 bispecific antibody, in patients with relapsed/refractory advanced multiple myeloma. Blood. 2018;132 Supplement 1:3229. doi:10.1182/blood-2018-99-110427

171. Raje NS, Jakubowiak A, Gasparetto C, et al. Safety, clinical activity, pharmacokinetics, and pharmacodynamics from a phase I study of PF-06863135, a B-cell maturation antigen (BCMA)CD3 bispecific antibody, in patients with relapsed/refractory multiple myeloma (RRMM). Blood. 2019;128:1869. doi:10.1182/ blood-2019-121805

172. Lesokhin AM, Levy MY, Dalovisio AP, et al. Preliminary safety, efficacy, pharmacokinetics, and pharmacodynamics of subcutaneously (SC) administered PF-06863135, a B-cell maturation antigen (BCMA)-CD3 bispecific antibody, in patients with relapsed/refractory multiple myeloma (RRMM). Blood. 2020;136 Supplement 1:8-9. doi:10.1182/blood-2020-133355

173. Bahlis NJ, Raje NS, Costello C, et al. Efficacy and safety of elranatamab (PF-06863135), a B-cell maturation antigen (BCMA)-CD3 bispecific antibody, in patients with relapsed or refractory multiple myeloma (MM). J Clin Oncol. 2021;39 15 suppl:8006. doi:10.1200/JCO.2021.39.15_suppl.8006

174. Pfizer, Inc. Pfizer initiates pivotal phase 2 MAGNETISMM-3 trial of BCMA-CD3 bispecific antibody elranatamab (PF-06863135) in multiple myeloma [press release]. New York, NY; 2021. Available from:https://www.pfizer.com/news/press-release/pressrelease-detail/pfizer-initiates-pivotal-phase-2-magnetismm-3-trialbcma. Accessed May 24, 2021.

175. Costa LJ, Wong SW, Bermúdez A, et al. First clinical study of the B-cell maturation antigen (BCMA) 2+1 T cell engager (TCE) CC-93269 in patients (pts) with relapsed/refractory multiple myeloma (RRMM): interim results of a phase 1 multicenter trial. Blood. 2019;134:143. doi:10.1182/blood-2019-122895

176. Trinklein ND, Pham D, Schellenberger U, et al. Efficient tumor killing and minimal cytokine release with novel T-cell agonist bispecific antibodies. mAbs. 2019;11(4):639-652. doi:10.1080/ 19420862.2019.1574521

177. Foureau DM, Bhutani M, Robinson M, et al. Ex vivo efficacy of BCMA-bispecific antibody TNB-383B in relapsed/refractory multiple myeloma. eJHaem. 2020;1(1):113-121. doi:10.1002/ jha2.69
178. Buelow B, Choudry P, Clarke S, et al. Pre-clinical development of TNB-383B, a fully human T-cell engaging bispecific antibody targeting BCMA for the treatment of multiple myeloma. J Clin Oncol. 2018;36(15Supplement):8034. doi:10.1200/ JCO.2018.36.15_suppl.8034

179. Buelow B, D’Souza A, Rodriguez C, et al. A multicenter, phase 1, open-label, dose-escalation and expansion study of TNB-383B, a bispecific antibody targeting BCMA in subjects with relapsed or refractory multiple myeloma. Blood. 2019;(134 Supplement 1):1874. doi:10.1182/blood-2019-123220

180. Rodriguez C, D'Souza A, Shah N, et al. Initial results of a phase I study of TNB-383B, a BCMA x CD3 bispecific T-cell redirecting antibody, in relapsed/refractory multiple myeloma. Blood. 2020;136 Supplement 1:43-44. doi:10.1182/blood-2020-139893

181. Law CL, Aaron W, Austin R, et al. Preclinical and nonclinical characterization of HPN217: a tri-specific T cell activating construct (TriTAC) targeting B cell maturation antigen (BCMA) for the treatment of multiple myeloma. Blood. 2018;132:3225. doi:10.1182/blood-2018-99-113921

182. Schade H, Madan S, Medvedova E, et al. HPN217-3001: a phase $1 / 2$ open-label, multicenter, dose escalation and dose expansion study of the safety, tolerability, and pharmacokinetics of HPN217, a Bcma-targeting T-cell engager, in patients with relapsed/refractory multiple myeloma. Blood. 2020;136:10. doi:10.1182/blood2020-136012

183. Smyth MJ, Cretney E, Kelly JM, et al. Activation of NK cell cytotoxicity. Mol Immunol. 2005;42(4):501-510. doi:10.1016/j. molimm.2004.07.034

184. Duell J, Lammers PE, Djuretic I, et al. Bispecific antibodies in the treatment of hematologic malignancies. Clin Pharmacol Ther. 2019;106(4):781-791. doi:10.1002/cpt.1396

185. Gantke T, Weichel M, Reusch U, et al. Trispecific antibodies for selective CD16A-directed NK-cell engagement in multiple myeloma. Blood. 2016;128:4513. doi:10.1182/blood.V128.22.4513.4513

186. Kakiuchi-Kiyota S, Schutten MM, Adedeji AO, et al. Preclinical pharmacology and safety of RO7297089, a novel anti-BCMA/ CD16a bispecific antibody for the treatment of multiple myeloma. Cancer Res. 2020;80(16Supplement):4556. doi:10.1158/15387445.Am2020-4556

187. Draghi M, Schafer JL, Nelson A, et al. Preclinical development of a first-in-class NKp30xBCMA NK cell engager for the treatment of multiple myeloma. Cancer Res. 2019;79:4972. doi:10.1158/ 1538-7445.AM2019-4972

188. Watkins-Yoon J, Guzman W, Oliphant A, et al. CTX-8573, an innate-cell engager targeting BCMA, is a highly potent multispecific antibody for the treatment of multiple myeloma. Blood. 2019;134:3182. doi:10.1182/blood-2019-128749

189. Li J, Stagg NJ, Johnston J, et al. Membrane-proximal epitope facilitates efficient $\mathrm{T}$ cell synapse formation by anti-FcRH5/CD3 and is a requirement for myeloma cell killing. Cancer Cell. 2017;31(3):383-395. doi:10.1016/j.ccell.2017.02.001

190. Cohen AD, Harrison SJ, Krishnan A, et al. Initial clinical activity and safety of BFCR4350A, a FcRH5/CD3 T-cell-engaging bispecific antibody, in relapsed/refractory multiple myeloma. Blood. 2020;136 Supplement 1:42-43. doi:10.1182/blood-2020-136985

191. Nakamura R, Lear S, Wilson D, et al. Early pharmacodynamic changes in T-cell activation, proliferation, and cytokine production confirm the mode of action of BFCR4350A, a FcRH5/CD3 T-cell-engaging bispecific antibody, in patients with relapsed/ refractory multiple myeloma. Blood. 2020;136 Supplement 1:14-15. doi:10.1182/blood-2020-136980

192. Richter JR, Landgren CO, Kauh JS, et al. Phase 1, multicenter, open-label study of single-agent bispecific antibody T-cell engager GBR 1342 in relapsed/refractory multiple myeloma. J Clin Oncol. 2018;36(15):2. doi:10.1200/JCO.2018.36.15_suppl.TPS3132 
193. Lum LG, Thakur A, Al-Kadhimi Z, et al. Induction of anti-myeloma cellular and humoral immunity by pre-targeting clonogenic myeloma cells prior to stem cell transplant with $\mathrm{T}$ cells armed with anti-CD3 $\mathrm{x}$ anti-CD20 bispecific antibody leads to transfer of cellular and humoral anti-myeloma immunity. Blood. 2013;122(21):139. doi:10.1182/blood.V122.21.139.139

194. Lum LG, Archana T, Muneer A, et al. Targeting myeloma stem cells with $\mathrm{T}$ cells armed with anti-CD3 $\mathrm{x}$ anti-CD20 bispecific antibody (CD20BI) prior to ASCT leads to development of anti-myeloma immune responses post autologous stem cell transplant that can be boosted with targeted T cells. Biology Blood Marrow Transplantation. 2012;18(2Supplement 2):S259. doi:10.1016/j.bbmt.2011.12.162

195. Verkleij CPM, Broekmans MEC, van Duin M, et al. Preclinical activity and determinants of response of the GPRC5DxCD3 bispecific antibody talquetamab in multiple myeloma. Blood Advances. 2021;5(8):2196-2215. doi:10.1182/bloodadvances.2020003805

196. Chari A, Berdeja JG, Oriol A, et al. A phase 1, first-in-human study of talquetamab, a $\mathrm{G}$ protein-coupled receptor family $\mathrm{C}$ group 5 member D (GPRC5D) x CD3 bispecific antibody, in patients with relapsed and/or refractory multiple myeloma (RRMM). Blood. 2020;136:40-41. doi:10.1182/blood-2020-133873

197. Kodama T, Kochi Y, Nakai W, et al. Anti-GPRC5D/CD3 bispecific $\mathrm{T}$ cell-redirecting antibody for the treatment of multiple myeloma. Mol Cancer Ther. 2019;18(9):1555-1564. doi:10.1158/1535-7163.Mct-18-1216

198. Topp M, Duell J, Zugmaier G, et al. Evaluation of AMG 420, an anti-BCMA bispecific T-cell engager $\left(\right.$ Bite $^{\mathbb{R}}$ ) immunotherapy, in R/R multiple myeloma (MM) patients: updated results of a first-Inhuman (FIH) phase 1 dose escalation study. J Clin Oncol. 2019;37 (15Supplement):8007. doi:10.1200/JCO.2019.37.15_suppl.8007

199. Cho S-F, Lin L, Xing L, et al. AMG 701, a half-life extended antiBCMA BiTE $^{\circledR}$, potently induces $\mathrm{T}$ cell-redirected lysis of human multiple myeloma cells and can be combined with IMiDs to overcome the immunosuppressive bone marrow microenvironment. Clin Lymphoma Myeloma Leuk. 2019;19(10):e54. doi:10.1016/j.clml.2019.09.082

200. Madduri D, Rosko A, Brayer J, et al. REGN5458, a BCMA $x$ CD3 bispecific monoclonal antibody, induces deep and durable responses in patients with relapsed/refractory multiple myeloma (RRMM). Blood. 2020;136 Supplement 1:41-42. doi:10.1182/ blood-2020-139192

201. Wall DA, Krueger J. Chimeric antigen receptor $\mathrm{T}$ cell therapy comes to clinical practice. Curr Oncol. 2020;27(Suppl 2):S115S123. doi:10.3747/co.27.5283

202. Rosenbaum L. Tragedy, perseverance, and chance - the story of CAR-T therapy. $N$ Engl $J$ Med. 2017;377(14):1313-1315. doi:10.1056/NEJMp1711886

203. Garfall AL, Stadtmauer EA, Hwang WT, et al. Anti-CD19 CAR $\mathrm{T}$ cells with high-dose melphalan and autologous stem cell transplantation for refractory multiple myeloma. JCI Insight. 2018;3 (8):e120505. doi:10.1172/jci.insight.120505

204. Neelapu SS, Locke FL, Bartlett NL, et al. Axicabtagene ciloleucel CAR T-cell therapy in refractory large B-cell lymphoma. $N$ Engl $J$ Med. 2017;377(26):2531-2544. doi:10.1056/NEJMoa1707447

205. Locke FL, Ghobadi A, Jacobson CA, et al. Long-term safety and activity of axicabtagene ciloleucel in refractory large B-cell lymphoma (ZUMA-1): a single-arm, multicentre, phase 1-2 trial. Lancet Oncol. 2019;20(1):31-42. doi:10.1016/s1470-2045(18)30864-7

206. Schuster SJ, Bishop MR, Tam CS, et al. Tisagenlecleucel in adult relapsed or refractory diffuse large B-cell lymphoma. $N$ Engl $J$ Med. 2019;380(1):45-56. doi:10.1056/NEJMoa1804980

207. Abramson JS, Gordon LI, Palomba ML, et al. Updated safety and long term clinical outcomes in TRANSCEND NHL 001, pivotal trial of lisocabtagene maraleucel (JCAR017) in R/R aggressive NHL. J Clin Oncol. 2018;36:7505. doi:10.1200/JCO.2018.36.15_suppl.7505
208. Muranski P, Boni A, Wrzesinski C, et al. Increased intensity lymphodepletion and adoptive immunotherapy-how far can we go? Nat Clin Pract Oncol. 2006;3(12):668-681. doi:10.1038/ncponc0666

209. Gattinoni L, Finkelstein SE, Klebanoff CA, et al. Removal of homeostatic cytokine sinks by lymphodepletion enhances the efficacy of adoptively transferred tumor-specific CD8+ T cells. J Exp Med. 2005;202(7):907-912. doi:10.1084/jem.20050732

210. Hirayama AV, Gauthier J, Hay KA, et al. The response to lymphodepletion impacts PFS in patients with aggressive non-Hodgkin lymphoma treated with CD19 CAR T cells. Blood. 2019;133(17):1876-1887. doi:10.1182/blood-2018-11-887067

211. Shimizu T, Nomiyama S, Hirata F, et al. Indoleamine 2,3-dioxygenase. Purification and some properties. J Biol Chem. 1978;253(13):4700-4706.

212. Ninomiya S, Narala N, Huye L, et al. Tumor indoleamine 2,3-dioxygenase (IDO) inhibits CD19-CAR T cells and is downregulated by lymphodepleting drugs. Blood. 2015;125 (25):3905-3916. doi:10.1182/blood-2015-01-621474

213. Balog A, Lin TA, Maley D, et al. Preclinical characterization of linrodostat mesylate, a novel, potent, and selective oral indoleamine 2,3-dioxygenase 1 inhibitor. Mol Cancer Ther. 2021;20 (3):467-476. doi:10.1158/1535-7163.Mct-20-0251

214. van de Donk N, Usmani SZ, Yong K. CAR T-cell therapy for multiple myeloma: state of the art and prospects. Lancet Haematol. 2021;8(6):e446-e461. doi:10.1016/s2352-3026(21)00057-0

215. Ali SA, Shi V, Maric I, et al. T cells expressing an anti-B-cell maturation antigen chimeric antigen receptor cause remissions of multiple myeloma. Blood. 2016;128(13):1688-1700. doi:10.1182/ blood-2016-04-711903

216. Brudno JN, Maric I, Hartman SD, et al. T cells genetically modified to express an anti-B-cell maturation antigen chimeric antigen receptor cause remissions of poor-prognosis relapsed multiple myeloma. J Clin Oncol. 2018;36(22):2267-2280. doi: $10.1200 /$ jco.2018.77.8084

217. Friedman KM, Garrett TE, Evans JW, et al. Effective targeting of multiple B-cell maturation antigen-expressing hematological malignances by anti-B-cell maturation antigen chimeric antigen receptor T Cells. Hum Gene Ther. 2018;29(5):585-601. doi:10.1089/hum.2018.001

218. U.S. Food and Drug Administration. FDA approves idecabtagene vicleucel for multiple myeloma [press release]. Washington, DC; 2021. Available from:https://www.fda.gov/drugs/resourcesinformation-approved-drugs/fda-approves-idecabtagene-vicleucel -multiple-myeloma. Accessed April 15, 2021.

219. Munshi NC, Anderson LD, Shah N, et al. Idecabtagene vicleucel in relapsed and refractory multiple myeloma. $N \mathrm{Engl} \mathrm{J} \mathrm{Med.}$ 2021;384(8):705-716. doi:10.1056/NEJMoa2024850

220. Zheng W, O'Hear CE, Alli R, et al. PI3K orchestration of the in vivo persistence of chimeric antigen receptor-modified T cells. Leukemia. 2018;32(5):1157-1167. doi:10.1038/s41375-017-0008-6

221. Berdeja JG, Alsina M, Shah ND, et al. 1. Blood. 2019;(134 Supplement 1):927. doi:10.1182/blood-2019-126660

222. Alsina M, Shah N, Raje NS, et al. Updated results from the phase I CRB-402 study of anti-Bcma CAR-T cell therapy bb21217 in patients with relapsed and refractory multiple myeloma: correlation of expansion and duration of response with T cell phenotypes. Blood. 2020;136 Supplement 1:25-26. doi:10.1182/blood-2020-140410

223. Xu J, Chen LJ, Yang SS, et al. Exploratory trial of a biepitopic CAR T-targeting B cell maturation antigen in relapsed/refractory multiple myeloma. Proc Natl Acad Sci U S A. 2019;116 (19):9543-9551. doi:10.1073/pnas.1819745116

224. Zhao WH, Liu J, Wang BY, et al. A phase 1, open-label study of LCAR-B38M, a chimeric antigen receptor T cell therapy directed against $\mathrm{B}$ cell maturation antigen, in patients with relapsed or refractory multiple myeloma. J Hematol Oncol. 2018;11(1):141. doi:10.1186/s13045-018-0681-6 
225. Zhao WH, Liu J, Wang BY, et al. Updated analysis of a phase 1, open-label study of LCAR-B38M, a chimeric antigen receptor $\mathrm{T}$ cell therapy directed against B-cell maturation antigen, in patients with relapsed/refractory multiple myeloma. Blood. 2018;132 Supplement 1:955. doi:10.1182/blood-2018-99-110548

226. Madduri D, Berdeja JG, Usmani SZ, et al. CARTITUDE-1: phase $1 \mathrm{~b} / 2$ study of ciltacabtagene autoleucel, a B-cell maturation antigen-directed chimeric antigen receptor $\mathrm{T}$ cell therapy, in relapsed/refractory multiple myeloma. Blood. 2020;(136 Supplement 1):22-25. doi:10.1182/blood-2020-136307

227. Legend Biotech Corp. U.S. Food and Drug Administration grants BCMA CAR-T cilta-cel priority review for the treatment for relapsed/refractory multiple myeloma [press release]. Somerset, NJ; 2021. Available from:https://www.businesswire.com/news/home/ 20210526006114/en/U.S.-Food-and-Drug-Administration-GrantsBCMA-CAR-T-Cilta-cel-Priority-Review-for-the-Treatment-forRelapsedRefractory-Multiple-Myeloma. Accessed June 4, 2021.

228. Agha ME, Cohen AD, Madduri D, et al. CARTITUDE-2: efficacy and safety of ciltacabtagene autoleucel (cilta-cel), a BCMA-directed CAR T-cell therapy, in patients with progressive multiple myeloma (MM) after one to three prior lines of therapy. J Clin Oncol. 2021;39 (15Supplement):8013. doi:10.1200/JCO.2021.39.15_suppl.8013

229. Goldberg SD, Cardoso RM, Lin T, et al. Engineering a targeted delivery platform using Centyrins. Protein Eng Des Sel. 2016;29 (12):563-572. doi:10.1093/protein/gzw054

230. Gattinoni L, Speiser DE, Lichterfeld M, et al. T memory stem cells in health and disease. Nat Med. 2017;23(1):18-27. doi:10.1038/nm.4241

231. Amatya C, Pegues MA, Lam N, et al. Development of CAR $\mathrm{T}$ cells expressing a suicide gene plus a chimeric antigen receptor targeting signaling lymphocytic-activation molecule. Mol Ther. 2020;29(2):702-717. doi:10.1016/j.ymthe.2020.10.008

232. Costello CL, Cohen AD, Patel KK, et al. Phase $1 / 2$ study of the safety and response of P-BCMA-101 CAR-T cells in patients with relapsed/refractory (R/R) multiple myeloma (MM) (PRIME) with novel therapeutic strategies. Blood. 2020;136 Supplement 1:29-30. doi:10.1182/blood-2020-142695

233. Mailankody S, Htut M, Lee KP, et al. JCARH125, anti-BCMA CAR T-cell therapy for relapsed/refractory multiple myeloma: initial proof of concept results from a phase 1/2 multicenter study (EVOLVE). Blood. 2018;132 Supplement 1:957. doi:10.1182/blood-2018-99-113548

234. Colonna L, Navarro G, Devries T, et al. Orvacabtagene autoleucel (orva-cel; JCARH125): a fully human BCMA-targeted second-generation CAR $\mathrm{T}$ cell product characterized by a predominant central memory phenotype with high in vitro and In vivo proliferative potential and sustained In vivo persistence. Blood. 2020;136 Supplement 1:957. doi:10.1182/blood-2020-136748

235. Mailankody S, Jakubowiak AJ, Htut M, et al. Orvacabtagene autoleucel (orva-cel), a B-cell maturation antigen (BCMA)-directed CAR T cell therapy for patients (pts) with relapsed/refractory multiple myeloma (RRMM): update of the phase 1/2 EVOLVE study (NCT03430011). J Clin Oncol. 2020;38(15Spplement):8504. doi:10.1200/JCO.2020.38.15_suppl.8504

236. Jiang S, Jin J, Hao S, et al. Low dose of human scFv-derived BCMA-targeted CAR-T cells achieved fast response and high complete remission in patients with relapsed/refractory multiple myeloma. Blood. 2018;132(Supplement 1):960. doi:10.1182/blood-2018-99113220

237. CARSgen Therapeutics Co. Ltd. CARsgen announces investigational CAR-T therapy CT053 granted RMAT designation by the U.S. FDA for R/R multiple myeloma [press release]. Shanghai, 2019. Available from:https://www.prnewswire.com/news-releases /carsgen-announces-investigational-car-t-therapy-ct053-grantedrmat-designation-by-the-us-fda-for-rr-multiple-myeloma -300945966.html. Accessed June 28, 2021.
238. Kumar SK, Baz RC, Orlowski RZ, et al. Results from Lummicar-2: a phase $1 \mathrm{~b} / 2$ study of fully human B-cell maturation antigen-specific CAR T cells (CT053) in patients with relapsed and/or refractory multiple myeloma. Blood. 2020;136 Supplement 1:28-29. doi:10.1182/blood-2020-139802

239. Wang D, Wang J, Hu G, et al. A phase 1 study of a novel fully human BCMA-targeting CAR (CT103A) in patients with relapsed/refractory multiple myeloma. Blood. 2021;137 (21):2890-2901. doi:10.1182/blood.2020008936

240. Xu J, Melenhorst J. CT103A, a forward step in multiple myeloma immunotherapies. Blood Science. 2021;3(2):59-61. doi:10.1097/ BS9.0000000000000068

241. Frigault MJ, O'Donnell E, Raje NS, et al. Phase 1 study of CART-ddBCMA, a CAR-T therapy utilizing a novel synthetic binding domain, for the treatment of subjects with relapsed and refractory multiple myeloma. J Clin Oncol. 2021;1 (15Supplement):8015. doi:10.1200/JCO.2021.39.15_suppl.8015

242. An G, Sui WW, Wang TY, et al. An anti-Bcma CAR T-cell therapy (C-CAR088) shows promising safety and efficacy profile in relapsed or refractory multiple myeloma. Blood. 2020;136 Supplement 1:29-30. doi:10.1182/blood-2020-138734

243. Lam N, Trinklein ND, Buelow B, et al. Anti-BCMA chimeric antigen receptors with fully human heavy-chain-only antigen recognition domains. Nat Commun. 2020;11(1):283. doi:10.1038/s41467-019-14119-9

244. Mikkilineni L, Manasanch EE, Vanasse D, et al. Deep and durable remissions of relapsed multiple myeloma on a first-in-humans clinical trial of $\mathrm{T}$ cells expressing an anti-B-cell maturation antigen (BCMA) chimeric antigen receptor (CAR) with a fully-human heavy-chain-only antigen recognition domain. Blood. 2020;136 (Supplement 1):50-51. doi:10.1182/blood-2020-138839

245. Zah E, Nam E, Bhuvan V, et al. Systematically optimized BCMA/ CS1 bispecific CAR-T cells robustly control heterogeneous multiple myeloma. Nat Commun. 2020;11(1):2283. doi:10.1038/ s41467-020-16160-5

246. Timmers M, Roex G, Wang Y, et al. Chimeric antigen receptor-modified $\mathrm{T}$ cell therapy in multiple myeloma: beyond B cell maturation antigen. Front Immunol. 2019;10:1613. doi:10.3389/fimmu.2019.01613

247. Jindal V, Khoury J, Gupta R, et al. Current status of chimeric antigen receptor T-cell therapy in multiple myeloma. Am J Clin Oncol. 2020;43(5):371-377. doi:10.1097/coc.0000000000000669

248. Huang H, Wu HW, Hu YX. Current advances in chimeric antigen receptor T-cell therapy for refractory/relapsed multiple myeloma. J Zhejiang Univ Sci B. 2020;21(1):29-41. doi:10.1631/jzus.B1900351

249. Li CG, Mei H, Hu Y, et al. A bispecific CAR-T cell therapy targeting BCMA and CD38 for relapsed/refractory multiple myeloma: updated results from a phase 1 dose-climbing trial. Blood. 2019;134 Supplement 1:930. doi:10.1182/blood-2019-130340

250. van der Schans JJ, van de Donk N, Mutis T. Dual targeting to overcome current challenges in multiple myeloma CAR T-cell treatment. Front Oncol. 2020;10:1362. doi:10.3389/ fonc. 2020.01362

251. Tang $\mathrm{F}, \mathrm{Lu} \mathrm{Y}, \mathrm{Ge} \mathrm{Y}$, et al. Infusion of chimeric antigen receptor T cells against dual targets of CD19 and B-cell maturation antigen for the treatment of refractory multiple myeloma. $J$ Int Med Res. 2020;48(1):300060519893496. doi:10.1177/0300060519893496

252. Yan L, Qu S, Shang J, et al. Sequential CD19 and BCMA-specific CAR T-cell treatment elicits sustained remission of relapsed and/ or refractory myeloma. Cancer Med. 2021;10:563-574. doi: $10.1002 / \mathrm{cam} 4.3624$

253. Jiang H, Dong BX, Gao L, et al. Clinical results of a multicenter study of the first-in-human dual BCMA and CD19 targeted novel platform fast CAR-T cell therapy for patients with relapsed/ refractory multiple myeloma. Blood. 2020;136 Supplement 1:25-26. doi:10.1182/blood-2020-138614 
254. Prommersberger S, Reiser M, Beckmann J, et al. CARAMBA: a first-in-human clinical trial with SLAMF7 CAR-T cells prepared by virus-free Sleeping Beauty gene transfer to treat multiple myeloma. Gene Ther. 2021. doi:10.1038/s41434-021-00254-w

255. Wang $X$, Walter $M$, Urak $R$, et al. Lenalidomide enhances the function of CS1 chimeric antigen receptor-redirected $\mathrm{T}$ cells against multiple myeloma. Clin Cancer Res. 2018;24 (1):106-119. doi:10.1158/1078-0432.Ccr-17-0344

256. Shah UA, Mailankody S. CAR T and CAR NK cells in multiple myeloma: expanding the targets. Best Pract Res Clin Haematol. 2020;33(1):101141. doi:10.1016/j.beha.2020.101141

257. Rodríguez-Lobato LG, Ganzetti M, Fernández de Larrea C. CAR T-cells in multiple myeloma: state of the art and future directions. Front Oncol. 2020;10:1243. doi:10.3389/fonc.2020.01243

258. Lamb MG, Rangarajan HG, Tullius BP, et al. Natural killer cell therapy for hematologic malignancies: successes, challenges, and the future. Stem Cell Res Ther. 2021;12:1. doi:10.1186/s13287021-02277-x

259. Rubio MT, Dhuyser A, Nguyen S. Role and modulation of NK cells in multiple myeloma. hemato. 2021;2(2):167-181. doi:10.3390/hemato2020010

260. Shimasaki N, Jain A, Campana D. NK cells for cancer immunotherapy. Nat Rev Drug Discov. 2020;19(3):200-218. doi:10.1038/s41573-019-0052-1

261. Chu J, Deng Y, Benson DM, et al. CS1-specific chimeric antigen receptor (CAR)-engineered natural killer cells enhance in vitro and in vivo antitumor activity against human multiple myeloma. Leukemia. 2014;28(4):917-927. doi:10.1038/ leu.2013.279

262. Jiang $H$, Zhang W, Shang P, et al. Transfection of chimeric anti-CD138 gene enhances natural killer cell activation and killing of multiple myeloma cells. Mol Oncol. 2014;8(2):297-310. doi:10.1016/j.molonc.2013.12.001

263. Sachdeva M, Busser BW, Temburni S, et al. Repurposing endogenous immune pathways to tailor and control chimeric antigen receptor T cell functionality. Nat Commun. 2019;10(1):5100. doi:10.1038/s41467-019-13088-3

264. Sommer C, Bentley T, Sutton J, et al. Off-the-shelf AlloCAR $\mathrm{T}$ (TM) cells targeting BCMA for the treatment of multiple myeloma. Clin Lymphoma Myeloma Leuk. 2019;19(10):E24. doi:10.1016/j.clml.2019.09.035

265. Allogene Therapeutics, Inc. Allogene Therapeutics announces FDA Regenerative Medicine Advanced Therapy (RMAT) designation granted to ALLO-715, an AlloCAR T ${ }^{\mathrm{TM}}$ cell therapy in development for relapsed/refractory multiple myeloma [press release]. South San Francisco, CA, 2021. Available from:https:// www.globenewswire.com/news-release/2021/04/21/2214140/0/ en/Allogene-Therapeutics-Announces-FDA-RegenerativeMedicine-Advanced-Therapy-RMAT-Designation-Granted-toALLO-715-an-AlloCAR-T-Cell-Therapy-in-Development-forRelapsed-Refractory-Mul.html. Accessed June 10, 2021.

266. Mailankody S, Matous JV, Liedtke M, et al. Universal: an allogeneic first-in-human study of the anti-Bcma ALLO-715 and the anti-CD52 ALLO-647 in relapsed/refractory multiple myeloma. Blood. 2020;1:24-25. doi:10.1182/blood-2020-140641

267. Tees MT, Neelapu SS, Hari P, et al. Safety and PK/PD of ALLO-647, an anti-CD52 antibody, with fludarabine (flu)/cyclophosphamide (cy) for lymphodepletion in the setting of allogeneic CAR-T cell therapy. J Clin Oncol. 2021;39(15supplement):2527. doi:10.1200/JCO.2021.39.15_suppl.2527

268. Prieto J, Redondo P, Lopez-Mendez B, et al. Understanding the indirect DNA read-out specificity of I-CreI meganuclease. Sci Rep. 2018;8(1):10286. doi:10.1038/s41598-018-28599-0
269. Jurica MS, Monnat RJ, Stoddard BL. DNA recognition and cleavage by the LAGLIDADG homing endonuclease I-CreI. Mol Cell. 1998;2(4):469-476. doi:10.1016/s1097-2765(00)80146-x

270. Precision Biosciences, Inc. Precision BioSciences receives fast track designation from U.S. Food and Drug Administration for PBCAR269A, an investigational allogeneic CAR $T$ therapy for relapsed/refractory multiple myeloma [press release]. Durham, NC, 2020. Available from:https://investor.precisionbiosciences. com/news-releases/news-release-details/precision-biosciencesreceives-fast-track-designation-us-food. Accessed June 11, 2021.

271. Da Vià MC, Dietrich O, Truger M, et al. Homozygous BCMA gene deletion in response to anti-BCMA CAR T cells in a patient with multiple myeloma. Nat Med. 2021;27:616-619. doi:10.1038/ s41591-021-01245-5

272. Madduri D, Parekh S, Campbell TB, et al. Anti-BCMA CAR $\mathrm{T}$ administration in a relapsed and refractory multiple myeloma patient after COVID-19 infection: a case report. J Med Case Rep. 2021;15(1):90. doi:10.1186/s13256-020-02598-0

273. Costa LJ, Lin Y, Martin TG, et al. Cilta-cel versus conventional treatment in patients with relapse/refractory multiple myeloma. Blood. 2021;39(Supplement 15):8030. DOI:10.1200/ JCO.2021.39.15_suppl.8030

274. Strohl WR, Naso M. Bispecific T-cell redirection versus chimeric antigen receptor (CAR)-T cells as approaches to kill cancer cells. Antibodies. 2019;8(3):41. doi:10.3390/antib8030041

275. Kennedy LB, Salama AKS. A review of cancer immunotherapy toxicity. CA Cancer J Clin. 2020;70(2):86-104. doi:10.3322/ caac. 21596

276. Shimabukuro-Vornhagen A, Godel P, Subklewe M, et al. Cytokine release syndrome. J Immunother Cancer. 2018;6 (1):56. doi:10.1186/s40425-018-0343-9

277. Yu J, Wang W, Huang H. Efficacy and safety of bispecific T-cell engager (BiTE) antibody blinatumomab for the treatment of relapsed/refractory acute lymphoblastic leukemia and nonHodgkin's lymphoma: a systemic review and meta-analysis. Hematology. 2019;24(1):199-207. doi:10.1080/ 16078454.2018.1549802

278. Aamir S, Anwar MY, Khalid F, et al. Systematic review and meta-analysis of CD19-specific CAR-T cell therapy in relapsed/ refractory acute lymphoblastic leukemia in the pediatric and young adult population: safety and efficacy outcomes. Clin Lymphoma Myeloma Leuk. 2021;21(4):E334-E347. doi:10.1016/ j.clml.2020.12.010

279. Wang Z, Han W. Biomarkers of cytokine release syndrome and neurotoxicity related to CAR-T cell therapy. Biomarker Research. 2018;6:4. doi:10.1186/s40364-018-0116-0

280. Billiau AD, Roskams T, Van Damme-lombaerts R, et al. Macrophage activation syndrome: characteristic findings on liver biopsy illustrating the key role of activated, IFN-gammaproducing lymphocytes and IL-6- and TNF-alpha-producing macrophages. Blood. 2005;105(4):1648-1651. doi:10.1182/ blood-2004-08-2997

281. Mehta P, McAuley DF, Brown M, et al. COVID-19: consider cytokine storm syndromes and immunosuppression. Lancet. 2020;395(10229):1033-1034. doi:10.1016/s0140-6736(20) 30628-0

282. Felsenstein S, Herbert JA, McNamara PS, et al. COVID-19: immunology and treatment options. Clin Immunol. 2020;215:108448. doi:10.1016/j.clim.2020.108448

283. Soy M, Keser G, Atagündüz $P$, et al. Cytokine storm in COVID-19: pathogenesis and overview of anti-inflammatory agents used in treatment. Clin Rheumatol. 2020:1-10. doi:10.1007/s10067-020-05190-5. 
284. Chen G, Wu D, Guo W, et al. Clinical and immunological features of severe and moderate coronavirus disease 2019. J Clin Invest. 2020;130(5):2620-2629. doi:10.1172/jci137244

285. U.S. Food and Drug Administration. FDA approves tisagenlecleucel for B-cell ALL and tocilizumab for cytokine release syndrome [press release]. Washington, DC, 2017. Available from:https://www.fda.gov/drugs/resources-information-approveddrugs/fda-approves-tisagenlecleucel-b-cell-all-and-tocilizumabcytokine-release-syndrome. Accessed June 26, 2021.

286. Neelapu SS. Managing the toxicities of CAR T-cell therapy. Hematol Oncol. 2019;37(Suppl 1):48-52. doi:10.1002/hon.2595

287. Si S, Teachey DT. Spotlight on tocilizumab in the treatment of CAR-T-cell-induced cytokine release syndrome: clinical evidence to date. Ther Clin Risk Manag. 2020;16:705-714. doi:10.2147/ tcrm.S223468

288. Freyer CW, Porter DL. Cytokine release syndrome and neurotoxicity following CAR T-cell therapy for hematologic malignancies. $J$ Allergy Clin Immunol. 2020;146(5):940-948. doi:10.1016/j. jaci.2020.07.025

289. Santomasso BD, Park JH, Salloum D, et al. Clinical and biological correlates of neurotoxicity associated with CAR T-cell therapy in patients with B-cell acute lymphoblastic leukemia. Cancer Discov. 2018;8(8):958-971. doi:10.1158/2159-8290.Cd-17-1319

290. Gust J, Hay KA, Hanafi LA, et al. Endothelial activation and blood-brain barrier disruption in neurotoxicity after adoptive immunotherapy with CD19 CAR-T cells. Cancer Discov. 2017;7 (12):1404-1419. doi:10.1158/2159-8290.Cd-17-0698

291. Yu S, Yi M, Qin S, et al. Next generation chimeric antigen receptor T cells: safety strategies to overcome toxicity. $\mathrm{Mol}$ Cancer. 2019;18(1):125. doi:10.1186/s12943-019-1057-4

292. Griffioen M, van Egmond EH, Kester MG, et al. Retroviral transfer of human CD20 as a suicide gene for adoptive T-cell therapy. Haematologica. 2009;94(9):1316-1320. doi:10.3324/ haematol.2008.001677

293. Liu YR, Chen Z, Fang HL, et al. Durable remission achieved from Bcma-directed CAR-T therapy against relapsed or refractory multiple myeloma. Blood. 2018;132(Supplement 1):956. doi:10.1182/blood-2018-99-112786

294. Fu WJ, Du J, Jiang H, et al. Efficacy and safety of CAR-T therapy with safety switch targeting Bcma for patients with relapsed/ refractory multiple myeloma in a phase 1 clinical study. Blood. 2019;134 Supplement 1:3154. doi:10.1182/blood-2019-127608

295. Di Stasi A, Tey SK, Dotti G, et al. Inducible apoptosis as a safety switch for adoptive cell therapy. $N$ Engl J Med. 2011;365 (18):1673-1683. doi:10.1056/NEJMoa1106152

296. Diaconu I, Ballard B, Zhang M, et al. Inducible caspase-9 selectively modulates the toxicities of CD19-specific chimeric antigen receptor-modified T cells. Mol Ther. 2017;25(3):580-592. doi:10.1016/j.ymthe.2017.01.011

297. Gargett T, Brown MP. The inducible caspase-9 suicide gene system as a "safety switch" to limit on-target, off-tumor toxicities of chimeric antigen receptor $\mathrm{T}$ cells. Front Pharmacol. 2014;5:235. doi:10.3389/fphar.2014.00235

298. Moghanloo E, Mollanoori H, Talebi M, et al. Remote controlling of CAR-T cells and toxicity management: molecular switches and next generation CARs. Transl Oncol. 2021;14(6):101070. doi:10.1016/j.tranon.2021.101070

299. Liao D, Wang M, Liao Y, et al. A review of efficacy and safety of checkpoint inhibitor for the treatment of acute myeloid leukemia. Front Pharmacol. 2019;10:609. doi:10.3389/fphar.2019.00609

300. Skarbnik AP, Donato ML, Feinman R, et al. Safety and efficacy of consolidation therapy with ipilimumab plus nivolumab after autologous stem cell transplantation. Transplant Cell Ther. 2021;27(5):391-403. doi:10.1016/j.jtct.2020.12.026
301. Mateos M-V, Orlowski RZ, Siegel DS, et al. Pembrolizumab in combination with lenalidomide and low-dose dexamethasone for relapsed/refractory multiple myeloma (RRMM): final efficacy and safety analysis. $J$ Clin Oncol. 2016;34((15 Supplement):8010). doi:10.1200/JCO.2016.34.15_suppl.8010

302. Pant A, Medikonda R, Lim M. Alternative checkpoints as targets for immunotherapy. Curr Oncol Rep. 2020;22(12):126. doi:10.1007/s11912-020-00983-y

303. Zhang C, Liu Y. Targeting NK cell checkpoint receptors or molecules for cancer immunotherapy. Front Immunol. 2020;11:1295. doi:10.3389/fimmu.2020.01295

304. Sun J, Muz B, Alhallak K, et al. Targeting CD47 as a novel immunotherapy for multiple myeloma. Cancers. 2020;12(2):305. doi:10.3390/cancers12020305

305. Patel K, Maris MB, Cheson BD, et al. Ongoing, first-in-human, phase I dose escalation study of the investigational CD47-blocker TTI-622 in patients with advanced relapsed or refractory lymphoma. J Clin Oncol. 2020;38:15. doi:10.1200/ JCO.2020.38.15_suppl.3030

306. Lucas F, Pennell M, Huang Y, et al. T-cell transcriptional profiling and immunophenotyping uncover LAG3 as a potential significant target of immune modulation in multiple myeloma. Biol Blood Marrow Transplant. 2019;26(1):7-15. doi:10.1016/j. bbmt.2019.08.009

307. Guillerey C, Harjunpää H, Carrié N, et al. TIGIT immune checkpoint blockade restores $\mathrm{CD} 8(+)$ T-cell immunity against multiple myeloma. Blood. 2018;132(16):1689-1694. doi:10.1182/blood2018-01-825265

308. Asimakopoulos F. TIGIT checkpoint inhibition for myeloma. Blood. 2018;132(16):1629-1630. doi:10.1182/blood-2018-08864231

309. Harjunpää H, Guillerey C. TIGIT as an emerging immune checkpoint. Clin Exp Immunol. 2020;200(2):108-119. doi:10.1111/cei.13407

310. Alfarra H, Weir J, Grieve S, et al. Targeting NK cell inhibitory receptors for precision multiple myeloma immunotherapy. Front Immunol. 2020;11:575609. doi:10.3389/fimmu.2020.575609

311. Paul B, Symanowski J, Osipoff P, et al. A phase 2 trial of daratumumab and pembrolizumab in refractory multiple myeloma. Blood. 2020;136 Supplement 1:2. doi:10.1182/blood2020-141623

312. Cho HJ, Costa LJ, Davies FE, et al. Atezolizumab in combination with daratumumab with or without lenalidomide or pomalidomide: a phase $\mathrm{Ib}$ study in patients with multiple myeloma. Blood. 2018;132:3. doi:10.1182/blood-2018-99-114960

313. Branagan A, Lei M, Lou U, et al. Current treatment strategies for multiple myeloma. JCO Oncol Pract. 2020;16(1):5-14. doi:10.1200/jop.19.00244

314. Cohen AD, Garfall AL, Stadtmauer EA, et al. B cell maturation antigen-specific CAR $\mathrm{T}$ cells are clinically active in multiple myeloma. J Clin Invest. 2019;129(6):2210-2221. doi:10.1172/ jci126397

315. Cohen AD, Garfall AL, Stadtmauer EA, et al. Safety and efficacy of B-cell maturation antigen (BCMA)-specific chimeric antigen receptor $\mathrm{T}$ cells (CART-BCMA) with cyclophosphamide conditioning for refractory multiple myeloma (MM). Blood. 2017;130(Supplement 1):505. doi:10.1182/blood.V130. Suppl_1.505.505

316. Green DJ, Pont M, Sather BD, et al. Fully human BCMA targeted chimeric antigen receptor $\mathrm{T}$ cells administered in a defined composition demonstrate potency at low doses in advanced stage high risk multiple myeloma. Blood. 2018;132(Supplement 1):1011. doi:10.1182/blood-2018-99-117729 
317. Hamieh M, Dobrin A, Cabriolu A, et al. CAR T cell trogocytosis and cooperative killing regulate tumour antigen escape. Nature. 2019;568:112-116. doi:10.1038/s41586-019-1054-1

318. Simoes RD, Shirasaki R, Downey-Kopyscinski SL, et al. Systematic characterization of genes representing preferential molecular vulnerabilities for myeloma cells compared to other neoplasias - implications for the biology and therapeutic targeting of myeloma. Blood. 2019;134(Supplement 1):4407. doi:10.1182/ blood-2019-130901

319. Smith EL, Harrington K, Staehr M, et al. GPRC5D is a target for the immunotherapy of multiple myeloma with rationally designed CAR T cells. Sci Transl Med. 2019;11:485. doi:10.1126/scitranslmed.aau7746

320. Atamaniuk J, Gleiss A, Porpaczy E, et al. Overexpression of G protein-coupled receptor $5 \mathrm{D}$ in the bone marrow is associated with poor prognosis in patients with multiple myeloma. Eur $J \quad$ Clin Invest. 2012;42(9):953-960. doi:10.1111/j.13652362.2012.02679.x
321. Bonello F, Grasso M, D'Agostino M, et al. The role of monoclonal antibodies in the first-line treatment of transplant-ineligible patients with newly diagnosed multiple myeloma. Pharmaceuticals. 2020;14(1):20. doi:10.3390/ph14010020

322. Holthof LC, Mutis T. Challenges for immunotherapy in multiple myeloma: bone marrow microenvironment-mediated immune suppression and immune resistance. Cancers. 2020;12(4):988. doi:10.3390/cancers 12040988

323. Kostopoulos IV, Ntanasis-Stathopoulos I, Gavriatopoulou M, et al. Minimal residual disease in multiple myeloma: current landscape and future applications with immunotherapeutic approaches. Front Oncol. 2020;10:860. doi:10.3389/ fonc. 2020.00860
ImmunoTargets and Therapy

\section{Publish your work in this journal}

ImmunoTargets and Therapy is an international, peer-reviewed open access journal focusing on the immunological basis of diseases, potential targets for immune based therapy and treatment protocols employed to improve patient management. Basic immunology and physiology of the immune system in health, and disease will be also covered. In addition, the journal will focus on the impact of management

\section{Dovepress}

programs and new therapeutic agents and protocols on patient perspectives such as quality of life, adherence and satisfaction. The manuscript management system is completely online and includes a very quick and fair peer-review system, which is all easy to use. Visit http://www.dovepress.com/testimonials.php to read real quotes from published authors. 